\title{
Albania: Ex Post Assessment of Longer-Term Program Engagement
}

This Ex Post Assessment of Longer-Term Program Engagement for Albania was prepared by a staff team of the International Monetary Fund as background documentation for the periodic consultation with the member country. It is based on the information available at the time it was completed on February 4, 2005. The views expressed in this document are those of the staff team and do not necessarily reflect the views of the government of Albania or the Executive Board of the IMF.

The policy of publication of staff reports and other documents by the IMF allows for the deletion of market-sensitive information.

To assist the IMF in evaluating the publication policy, reader comments are invited and may be sent by e-mail to publicationpolicy@imf.org.

Copies of this report are available to the public from

International Monetary Fund $\bullet$ Publication Services

700 19th Street, N.W. • Washington, D.C. 20431

Telephone: (202) 6237430 • Telefax: (202) 6237201

E-mail: publications@imf.org • Internet: http://www.imf.org

Price: $\$ 15.00$ a copy

\section{International Monetary Fund Washington, D.C.}





\section{INTERNATIONAL MONETARY FUND}

\section{ALBANIA \\ Ex Post Assessment of Longer-Term Program Engagement}

Prepared by a Staff Team from EUR, FAD, and PDR

Authorized for distribution by the European and Policy and Development Review Departments

February 4, 2005

I. Introduction

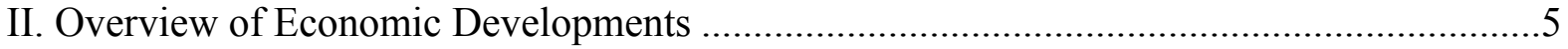

III. Achievements and Continuing Challenges Under Fund-Supported Programs...................8

IV. Benefits of Fund Support, Conditionality, and Bank-Fund Collaboration.......................32

V. Considerations for Future Program Engagement ...................................................... 37

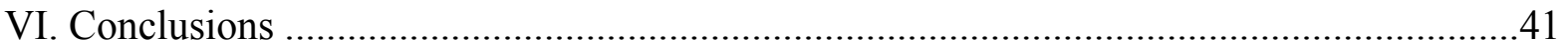

Figures

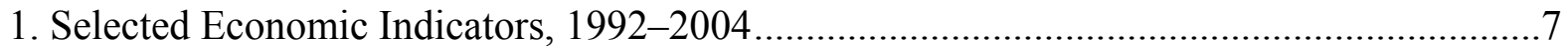

2. Projections and Outtun of Inflation, Current Account Deficit, and

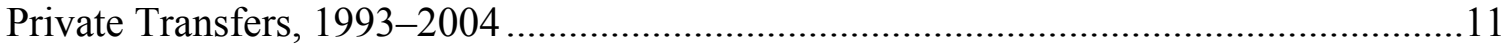

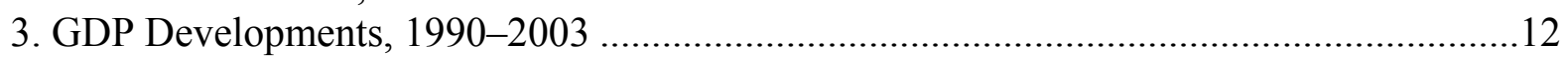

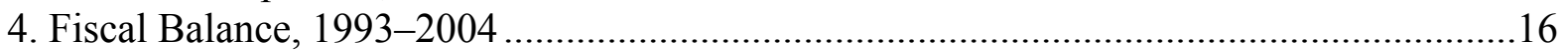

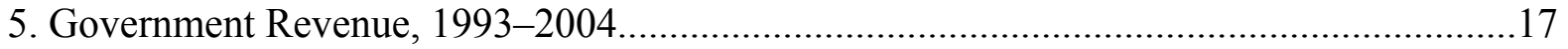

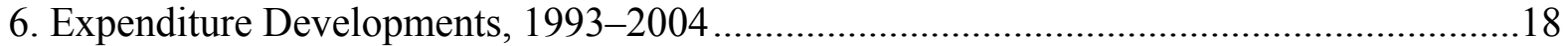

7. Expenditure on Priority Areas, 1998-2003 ......................................................................19

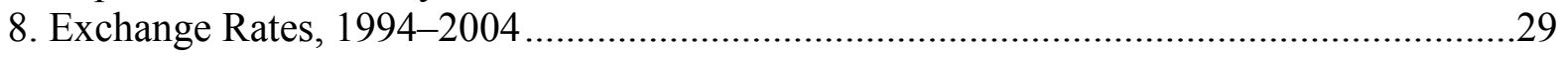

Tables

1. History of Fund-Supported Arrangements ...............................................................

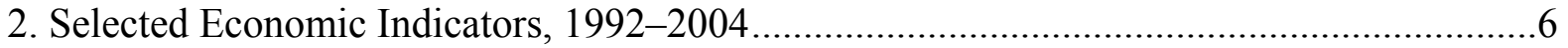

3. Government Revenues and Expenditures, 1992-2004 ..............................................15

4. Deviations in Tax Collections from Budgeted Levels, 1998-2004 ..................................20 
5. Comparative Structure of Tax Revenue in Selected Eastern European

Countries, 2001-02

6. Projections and Outturn of Private Remittances, 1993-2003 _.........................................24

7. Budgetary Sphere Employment and Wage Developments, 1992-2003 ..........................25

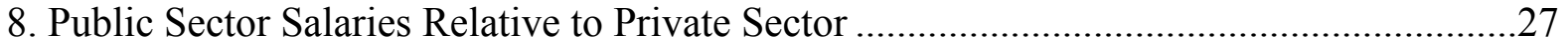

9. Sources of External Financing, 1992-2003 ….................................................................34

10. Structural Conditionality and Performance under Fund-Supported Programs ..................36 


\section{INTRODUCTION}

1. Since 1991, when its isolationist rule came to an end, Albania has made significant headway in securing macroeconomic stability and in transforming the economy into a market-based system. Still, in part reflecting its precarious starting point, Albania remains one of the poorest countries in the region, with considerable shortcomings in the governance and institutional frameworks and with enormous infrastructure needs. Albania also remains vulnerable to domestic political and regional instability.

\section{Episodes of political uncertainty and social instability have hindered policy} making and implementation. Election considerations eroded the government's policy resolve in the first half of 1996. In early 1997, the collapse of the financial pyramid schemes triggered a near civil war-like situation, with the government losing control over large parts of the country. An episode of civil unrest in September 1998, in the wake of the shooting of a prominent opposition politician, resulted in a change of government. The crisis in Kosovo in March 1999 precipitated a flood of refugees into Albania which placed considerable strain on the social and economic infrastructure. Political divisions led to three changes in government within the first twelve months after the June 2001 elections, and infighting within the ruling socialist party continued in 2003. With Albania's politics remaining relatively divisive and confrontational, and parliamentary elections scheduled for mid-2005, political economy considerations are likely to play an important role in policy making in the period ahead.

\section{Albania has been engaged in a series of Fund-supported programs since the} beginning of transition, with two interruptions. A Stand-By arrangement (SBA) in 1992-93 was followed by a three-year arrangement under the Enhanced Structural Adjustment Facility (ESAF), which lapsed after two years as understandings could not be reached on the third annual program. In the second half of 1997, following the pyramid scheme crisis, a six-month program was supported under the Fund's post-conflict emergency assistance policy. This was followed by two ESAF/PRGF ${ }^{1}$ arrangements, with a one-year hiatus in between during 2001-02 owing to the prevailing uncertain political climate. The current PRGF arrangement will expire in June 2005 (Table 1). Altogether, Albania has been engaged in Fund-supported programs for 110 out of 148 months during September 1992December 2004.

\section{This report presents an ex post assessment (EPA) of Albania's longer-term program engagement with the Fund. ${ }^{2}$ Section II provides an overview of economic}

\footnotetext{
${ }^{1}$ Poverty Reduction and Growth Facility.

${ }^{2}$ This report was prepared by a team consisting of Messrs. Banerjee (EUR, head), Çakir (FAD), Lazar (EUR), and Mansilla (PDR). The report is based on the analysis of Fund documents as well as on discussions with current and former mission chiefs, former resident representatives, tax experts who participated in technical assistance missions to Albania, World Bank staff, and a former senior official of the Bank of Albania.
} 


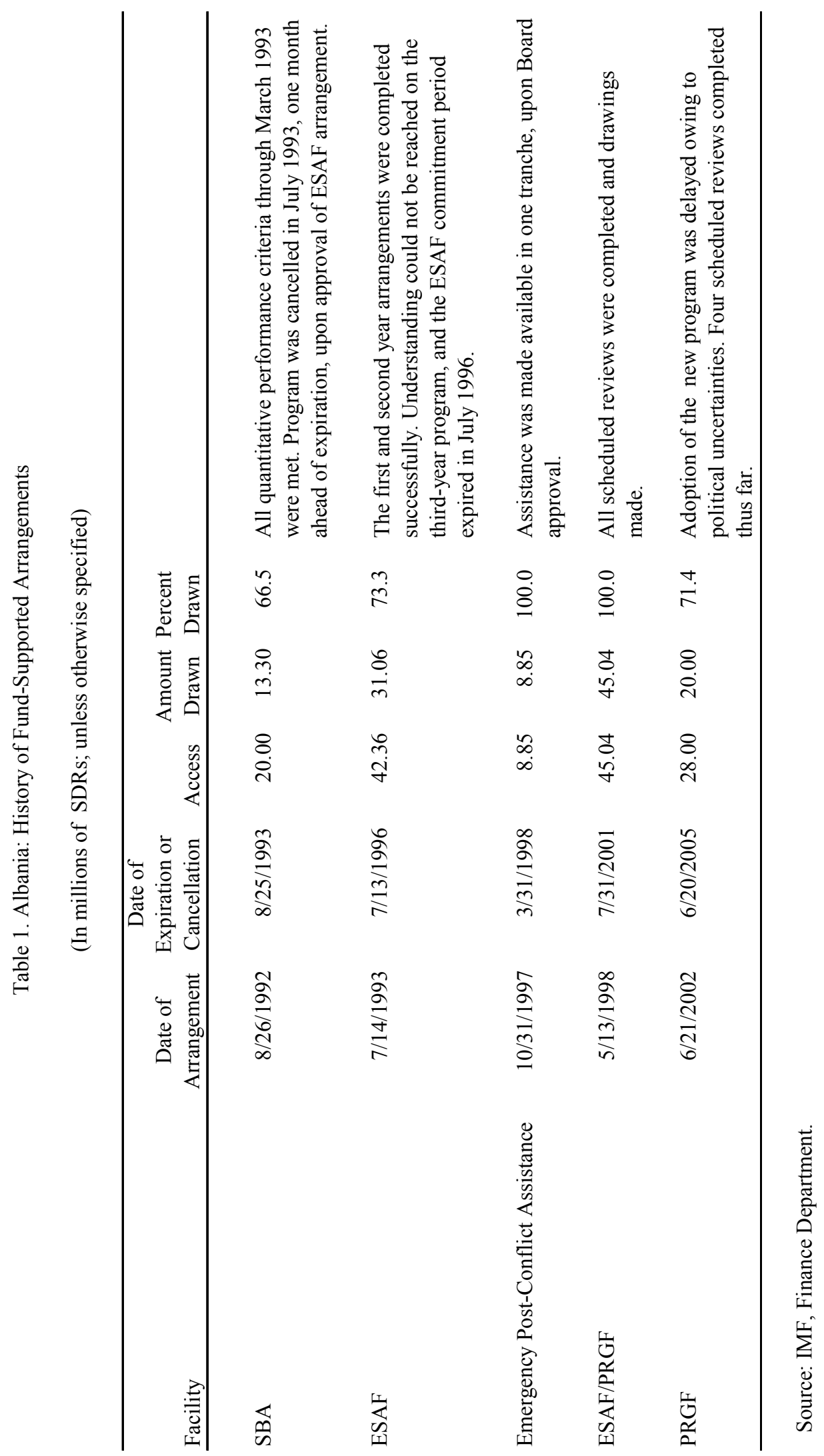


developments. Section III discusses the overall role of the Fund, reviews the implementation of financial policies, and looks into selected dimensions of structural policies. Section IV summarizes the record on meeting conditionality and the nature of Bank-Fund collaboration. Section V examines the considerations for future program engagement, and Section VI concludes.

\section{OVERVIEW OF ECONOMIC DEVELOPMENTS}

5. The period since transition can be divided into three phases: (i) the post-transition slump and restoration of macroeconomic stability (1991-95); (ii) a period of faltering policies and a severe economic fallout from the collapse of the pyramid schemes (1996-mid 1997); and (iii) a period of post-conflict stabilization and renewed reform (mid 1997-2004). The salient aspects of each period are as follows.

\section{A. Phase 1: The First Years of Transition}

\section{The initial post-transition slump was steep, but Albania made exceptional} progress during 1993-95 under Fund-supported programs. By 1992, output had contracted by one third from its 1990 level, inflation had risen to triple digits, and the external current account deficit was equivalent to almost 40 percent of GDP. Economic activity rebounded sharply thereafter, with real GDP growing by around 9 percent annually during 1993-95. ${ }^{3}$ By 1995, annual inflation had fallen to single digits, the external current account deficit was reduced sharply to $6 \frac{1}{2}$ percent of GDP, the dependence on foreign aid had decreased markedly, and foreign reserves were rebuilt to the equivalent of almost three months of imports from about one month in 1992 (Table 2 and Figure 1). The key factors contributing to this strong rebound included fiscal tightening; financial discipline at the state enterprise levels; early privatization of large tracts of the economy, including agriculture; elimination of almost all price controls; and sweeping liberalization of the exchange and trade systems. The building blocks of a modern tax system, a two-tier banking system, and the basic legal framework for a market economy were also put in place during this period.

\section{B. Phase 2: Sliding into Crisis}

7. In 1996, the government's policy resolve faltered ahead of the elections, prompting the Fund to disengage from a program mode. Structural reforms were delayed. The progress in fiscal consolidation stalled, as politically motivated reductions in some tax rates and less vigorous enforcement of tax collection resulted in considerable

\footnotetext{
${ }^{3}$ Data on national accounts and other economic activity indicators in Albania are weak. Data problems are accentuated by a large agricultural sector and sizeable informal economy. The official national accounts data include an estimate of the informal economy which is subject to debate. While the precision of the GDP growth estimates may be uncertain, the broad tendencies would seem to be plausible.
} 


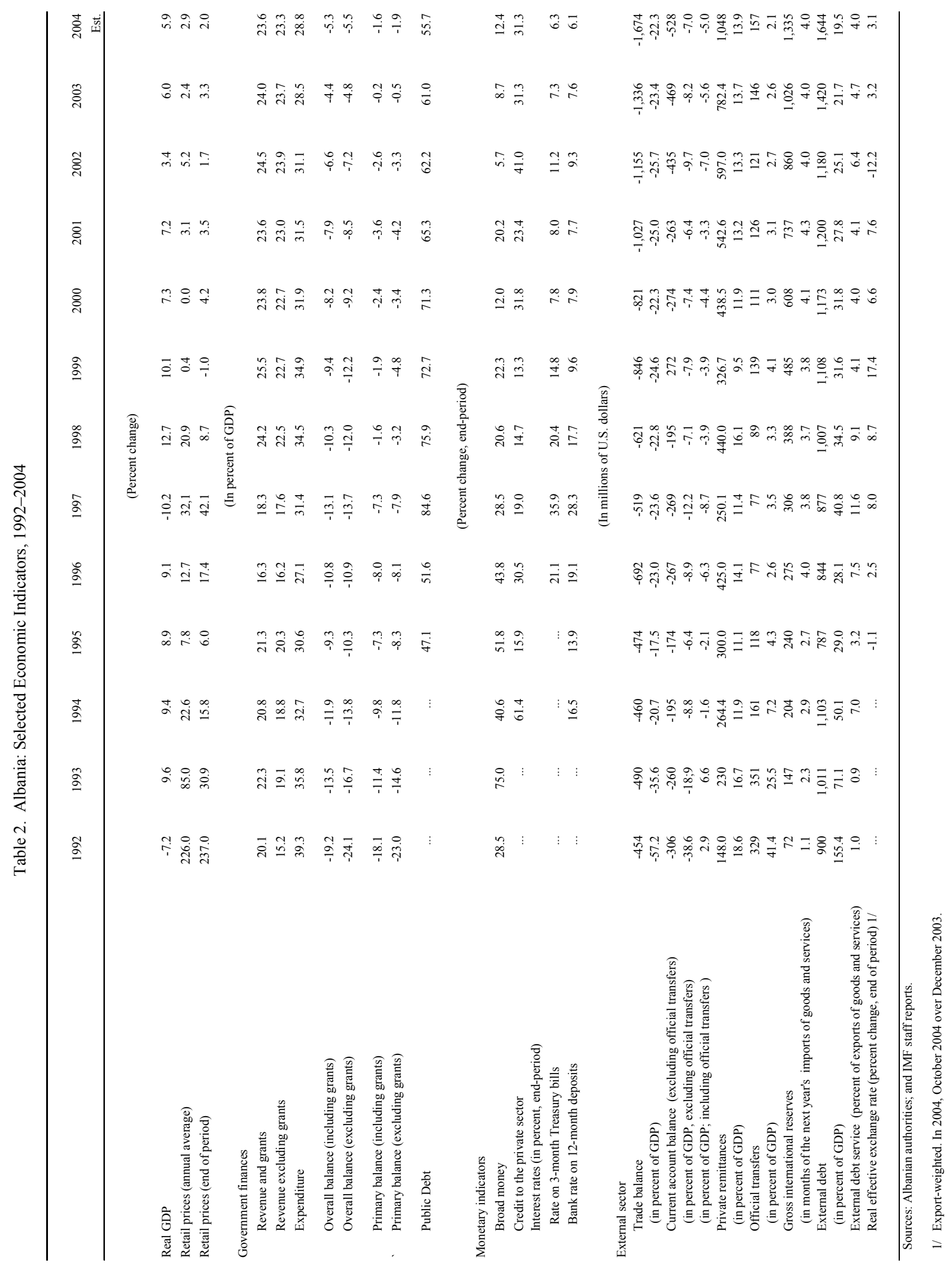


Figure 1. Albania: Selected Economic Indicators, 1992-2004

REAL GDP

(Percent change)

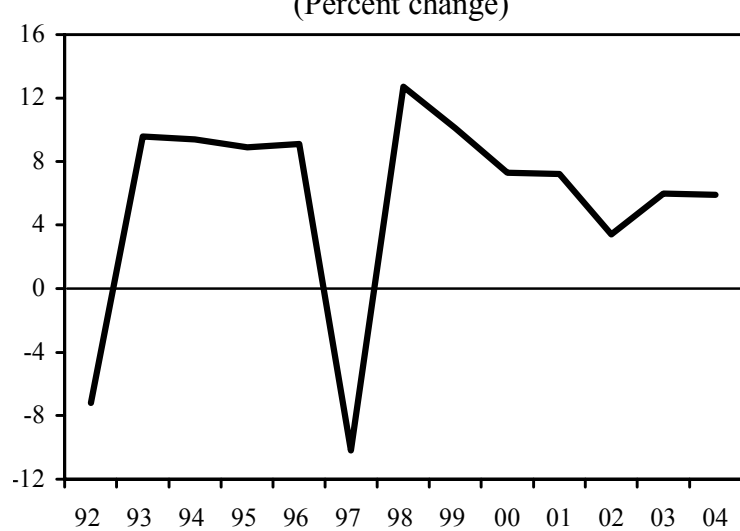

CURRENT ACCOUNT BALANCE 2/

(In percent of GDP)

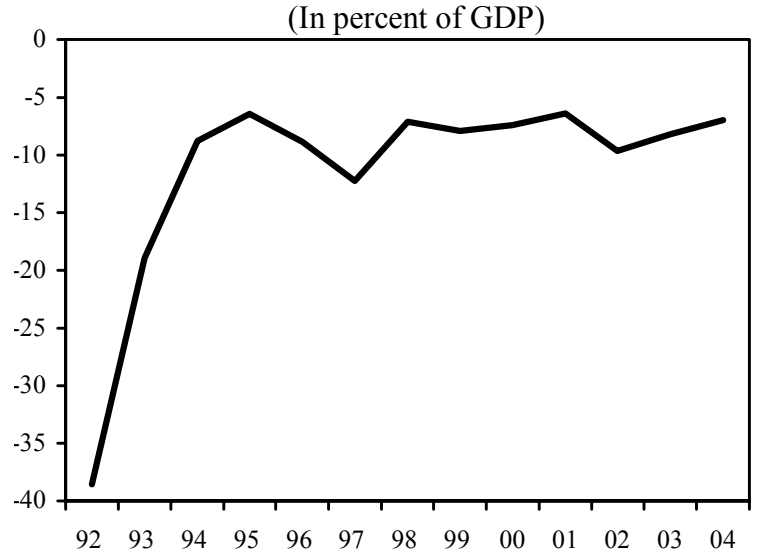

GROSS INTERNATIONAL RESERVES

(In months of imports of goods \& services)

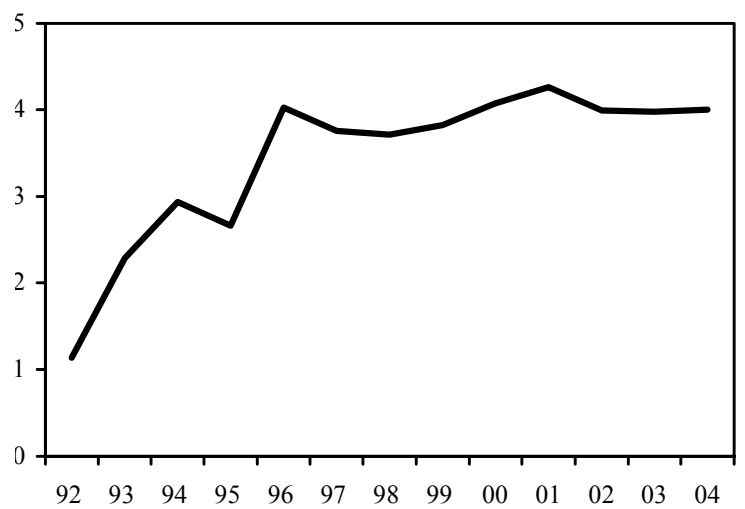

RETAIL PRICE INFLATION 1/

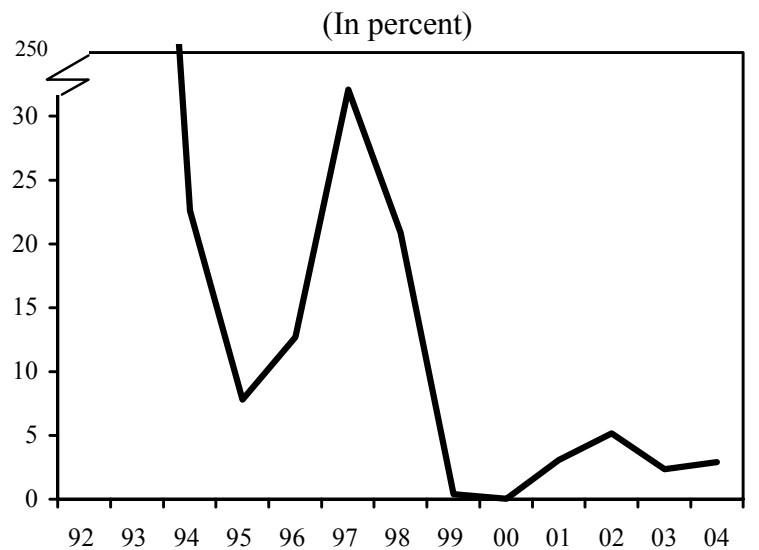

PRIVATE AND OFFICIAL TRANSFERS

(In percent of GDP)

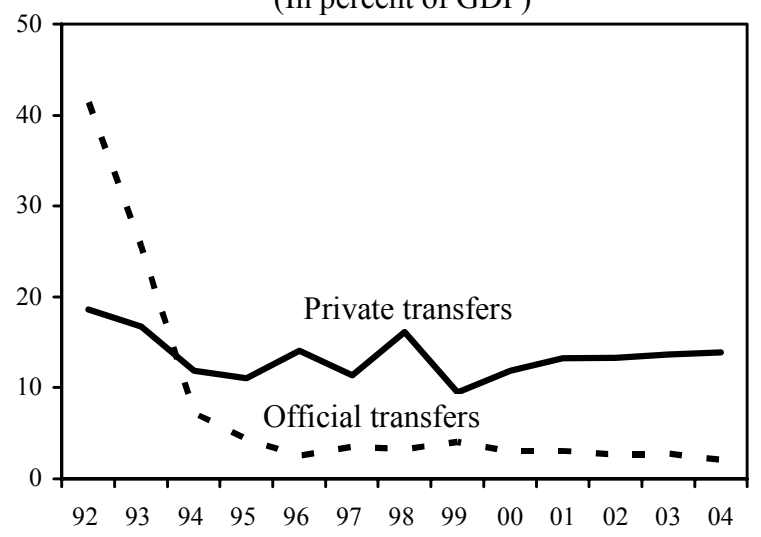

DEBT

(In percent of GDP)

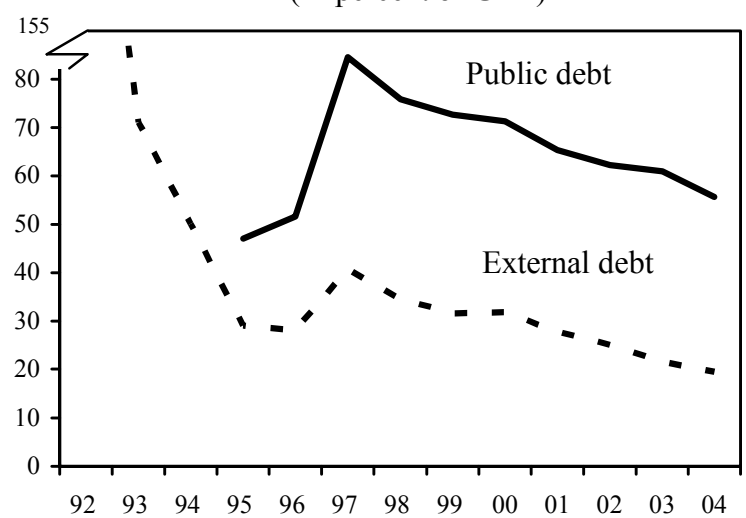

Sources: Albanian authorities; and IMF staff reports.

1/ Annual average. Figures for 1992 and 1993 are 226 and 85 percent, respectively.

2/ Excludes official transfers. 
revenue loss. The introduction of a VAT in place of the turnover tax in July, after the elections, did not improve the revenue potential much as the rate was set too low. Financial pyramid schemes mushroomed on an unprecedented scale during the year-nominal liabilities of these schemes are estimated to have reached nearly 50 percent of GDP by end1996. With the illusory increase in wealth fueling domestic demand and imports, GDP growth remained rapid, the end-year inflation rate nearly tripled, and the current account deficit widened.

8. In early 1997, Albania plunged into a deep economic and social crisis. A collapse of the pyramid schemes triggered large-scale social unrest and widespread destruction of public facilities, including most customs posts and many tax offices. The government's authority crumbled completely. Economic activity contracted steeply owing to supply disruptions as well as depressed demand. Tax collections dropped. The lek depreciated by over 40 percent during the first half of the year, as remittances from abroad declined markedly and foreign aid virtually ceased. Consequently, inflation soared. The Bank of Albania increased interest rates sharply during this period and refrained from significant foreign exchange market intervention, thereby avoiding depletion of official reserves.

\section{Phase 3: Post-crisis Recovery and Renewal of Reforms}

9. The political landscape changed following elections in mid-1997, and the new government embarked on a two-stage strategy to put the Albanian economy on a stable path of recovery and reform, with support from the Fund. Macroeconomic stability was speedily restored and sustained. Economic activity rebounded strongly from the crisis-related downturn and the pace of real GDP growth settled at around 7 percent in 2000-01. Severe energy shortages and floods resulted in a marked slowdown in activity in 2002, but the growth momentum recovered the following year. Inflation came down sharply from its 1997 peak, and has generally remained in the $2-4$ percent range since late-2002. Confidence in the lek also returned quickly with political and economic stability. After an initial narrowing, the external current account deficit fluctuated in the 7-8 percent of GDP range during 1998-2004. A new tax package introduced in October 1997, including an increase in the VAT rate from $12^{1 / 2}$ percent to 20 percent, substantially strengthened the fiscal framework. In conjunction with other measures, the overall budget deficit was brought down progressively. The structural reform agenda since mid-1997 has included liquidating the pyramid schemes; strengthening tax and customs administration; enhancing the efficiency of the civil service; improving public expenditure management; privatizing state-owned banks and setting the foundations for a modern financial sector; accelerating enterprise privatization; creating a functioning market in agricultural land; and addressing Albania's governance weaknesses.

\section{ACHIEVements And Continuing Challenges UNDER Fund-SUPPORTED PROGRAMS}

10. Albania's prolonged use of Fund resources, and the detailed and comprehensive nature of the programs on the basis of which these resources were provided, have been appropriate considering that Albania's starting conditions were perhaps the worst of 
any transition country. Decades of strict central planning and self-imposed isolation had progressively weakened the economy and left it completely ill-prepared for the transition to a market economy. Institutional structures were rudimentary and weak. The harshness of the communist regime had instilled a strong distrust in the state among the Albanian people. Thus, a complete overhaul of Albania's economic and social institutions was needed, under economic conditions that could hardly be worse. Following the discarding of the old order, output fell to a level comparable to the poorest regions in the world and inflation was spiraling upward.

\section{Albania has come a long way from this starting point, with significant} accomplishments but also continuing challenges. This experience is reviewed thematically in this section. Section III.A provides a bird's eye view of the role of the Fund in Albania's transition. This discussion is followed, in sections III.B-III.D, by an examination of various dimensions of policy implementation, notably as regards budgetary management and structural policy delays or failures.

\section{A. The Role of the Fund-Overview}

\section{The evolving objectives of Fund-supported programs}

12. The main objectives and policies of Fund-supported programs have generally been sound, having been changed in an appropriate and timely manner as circumstances have evolved. Under the SBA in 1992, at the beginning of transition, and during the program supported by post-conflict emergency assistance in the second half of 1997, after the pyramid scheme crisis, the primary aim was to stabilize the financial situation and arrest the downward slide of the economy. Nevertheless, even though policy-making was dictated by the crisis situation, both these programs were intended to be precursors to programs with a medium-term horizon. Thus, the first steps of major structural measures were also taken. Under the SBA, a priority was to inject market forces into the economy and establish an appropriate relative price structure at the very outset of the transition process. Under the post-conflict emergency assistance, priority was given to creating a solid foundation for fiscal consolidation, taking control of the pyramid schemes and winding them up, and preparing the state-owned banks for privatization and liquidation.

\section{The main goals of the ESAF-supported programs that followed these two} shorter-term programs were to consolidate the initial achievements in stabilization and to lay the foundation for sustained growth through a wide-array of structural reforms. From 2000, mid-way through one of the ESAF/PRGF arrangements, new emphasis was put on inclusive growth and poverty reduction. Accordingly, the focus of policies was broadened to include reorienting government spending toward priority areas for poverty reduction while ensuring fiscal sustainability, and improving governance and the business climate for the private sector. 


\section{Performance under Fund-supported programs}

14. The macroeconomic objectives of the Fund-supported programs were generally achieved. Financial policies were decisively implemented, fostering macroeconomic stability and growth. In most years, the inflation and external current account deficit outturn were lower than projected under the programs, and the growth performance was in line with program expectations (Figure 2). More striking, inflation has been brought down to the levels of Albania's main trading partners in the European Union. Although Albania's initial posttransition slump was steeper than that in the other transition countries in central and eastern Europe, Albania has caught up with other transition countries in the cumulative increase in real GDP since the beginning of the transition process (Figure 3). Fiscal consolidation, together with rapid growth, contributed to a significant reduction in both the external and public debt burden. As ratio to GDP, external debt declined by one half from the time of the 1997 crisis to 20 percent of GDP at end-2004. Over the same period, public sector debt fell by over one fourth to 56 percent of GDP.

\section{Implementation of structural reforms proceeded at an uneven pace, but was} satisfactory overall. In general, measures that had an immediate impact on stabilization were implemented in a timely manner, whereas measures important over the medium term were subject to delays. In macro-critical areas, the authorities persisted in staying the course and progress did take place incrementally. There has been substantial - even if still incomplete - progress in building the institutional foundations of sound macroeconomic policies. In addition, public administration has been rationalized, the government's role in production has been reduced sharply, and the commercial banking sector is now entirely in private hands. However, implementation of measures in areas outside the Fund's mandate and not covered by conditionality - for example, law enforcement and fight against corruption-has been weak.

16. However, the achievements remain fragile. Risks remain on account of pervasive poverty, lingering administrative capacity weaknesses, continued divisive politics, and slow progress in improving governance. The virulence of the pyramid scheme crisis of early 1997 is a reminder of the potential fragility of the situation. While partial indicators suggest that poverty may have decreased over time, the 2002 Living Standard Measurement Survey found that one fourth of the Albanian population lived below the absolute poverty line and that the non-income dimensions of poverty were also high. In the context of governance weaknesses, there is concern about the quality and sustainability of the strong growth performance.

\section{Aspects of program implementation}

\section{Ownership of the program agenda was a key factor in the successful}

implementation of the programs. Except during 1996-mid 1997, the authorities stayed committed to taming inflation and maintaining price stability and to safeguarding fiscal and external sustainability. Even during the Kosovo crisis, the authorities pursued cautious financial policies, though structural reforms suffered. 
Figure 2. Albania: Projections and Outturn of Inflation, Current Account Deficit, and Private Transfers, 1993-2004
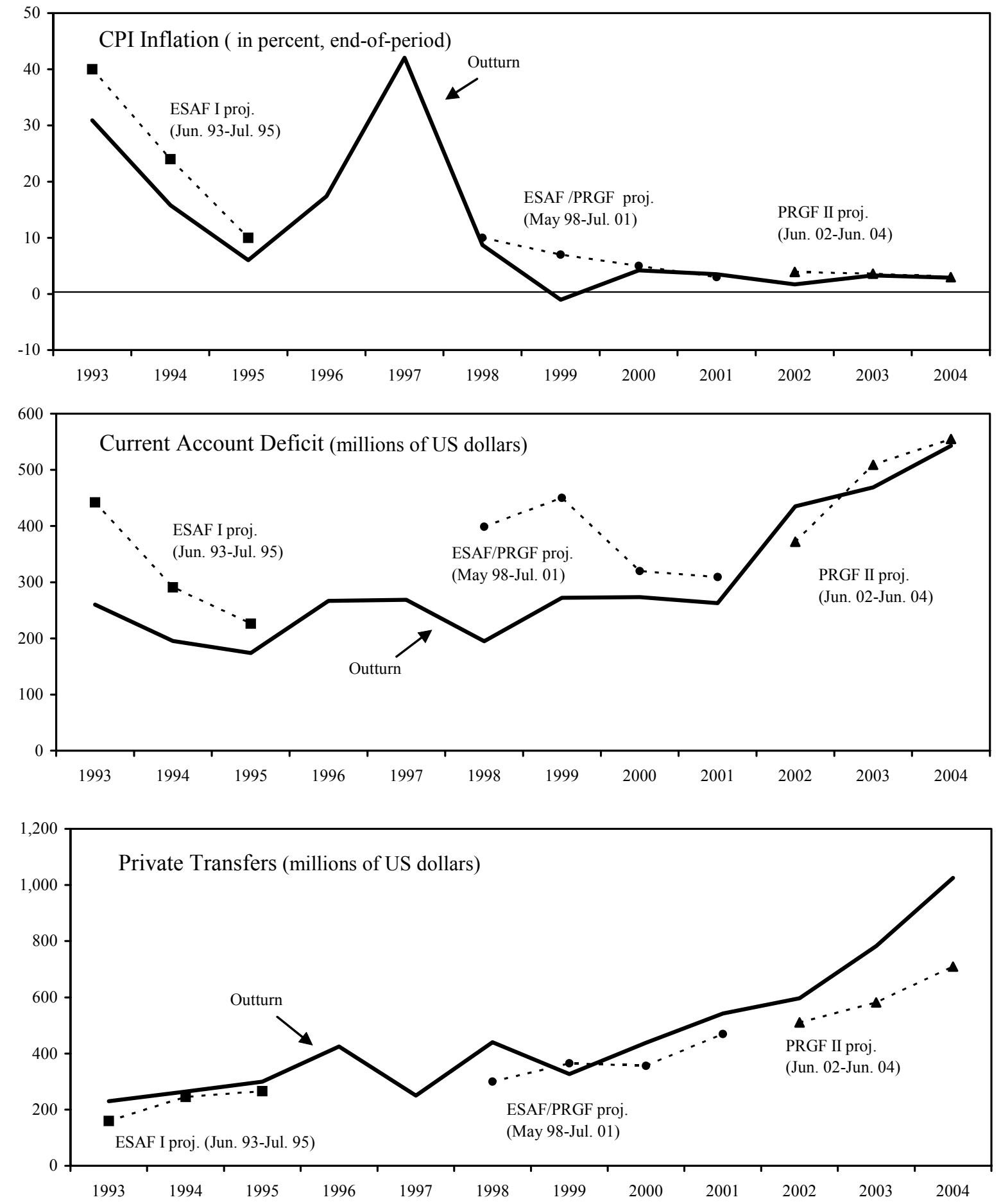

Source: IMF Staff reports. 
Figure 3. Albania: GDP developments, 1990-2003
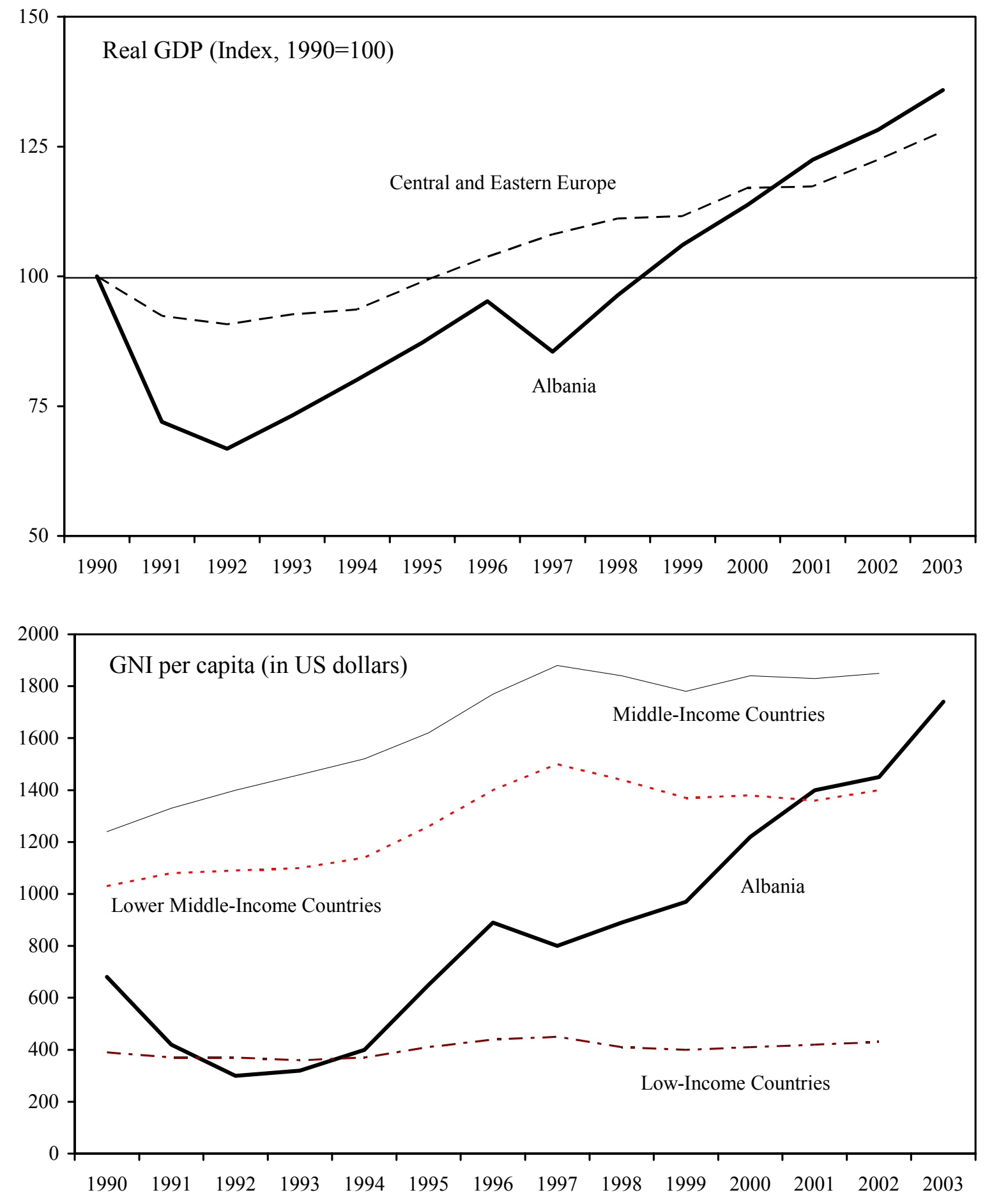

Sources: Albanian authorities; World Economic Outlook; and World Development Indicators database. 
18. The approach to program design and conditionality was detailed, hard-nosed, and increasingly complemented by capacity building. In view of the authorities' limited capacity to formulate and implement macroeconomic policies and structural measures, all the programs were covered by very detailed conditionality, which served as a blueprint for reforms, kept the authorities focused, and helped mobilize internal support for the adjustment and reform efforts. This was complemented by extensive technical assistance from both bilateral and multilateral sources to improve institutional and administrative capacity, with key contributions from the Fund. Given the institutional weaknesses, structural measures in the early years of transition were chosen to concentrate on the most pressing issues. As reform efforts became more broad-based and more complex than the first round of structural changes under the SBA, administrative weaknesses often became binding or political interests came to the forefront, thereby leading to implementation delays. Sometimes, though, delays arose from circumstances beyond the control of the authorities, such as a weakening global market environment and the Kosovo crisis. Generally, in the event of implementation delays, the missed measures were converted into prior actions for completion of the program review or, if appropriate, deadlines were moved back and the authorities reiterated their intentions to stay the course. When uncertainties were deemed to be particularly high - such as at the start of the 1992 SBA, the program supported by emergency assistance in 1997, and the first-year program under the succeeding ESAF arrangement in 1998 - most of the key structural measures were implemented as prior actions.

\section{Program-based engagement ebbed and flowed with ownership}

\section{The interruptions in program-based engagement were triggered by faltering} policies or by uncertainties about program ownership. Thus, in 1996, understandings could not be reached on the third-year program under the ESAF arrangement because of election-related policy slippage and the government's unwillingness to take sufficient corrective measures after the elections. Governance was weak during this period and developments eventually culminated in the pyramid scheme crisis in early 1997 . The circumstances surrounding the second interruption were different. Final understandings on the current PRGF arrangement were kept pending for almost one year during 2001-02 because of elections and subsequent political feuds that led to three changes in government. However, the entire period of this second hiatus was covered by interim understandings on a detailed policy framework. Thus, unlike in the first period of disengagement, there was no deterioration in the macroeconomic situation, though progress in structural reforms was stifled. The Fund re-engaged in program mode after both interruptions once the political climate stabilized and the authorities showed credible commitment to renewing adjustment and reform efforts.

\section{B. Fiscal Policy Implementation}

20. Fiscal consolidation has been the centerpiece of the authorities' economic policies since the beginning of transition. The budget deficit (including grants) declined from about 19 percent of GDP in 1992 to 51/4 percent of GDP in 2004. Domestic borrowing by the budget was consistently in line with the programmed limits. However, the overall 
deficit outturn always was lower than envisaged under the program, owing to shortfalls in foreign-financing. Although the fiscal consolidation was impressive, the budget formulation process was weak and the objective of higher pro-poor spending was not met. The discussion below sheds further light on these and other dimensions of fiscal policy execution.

\section{Albania's fiscal adjustment has been striking, but marred by enduring problems of composition.}

- The improvement in the fiscal position was particularly sharp in the initial phase of transition, when the budget deficit fell by 10 percentage points of GDP during 1992-95. The fiscal position deteriorated during 1996-97. Since 1998, when the fullyear effect of the October 1997 tax package went into force, the budget deficit has dropped by 5 percentage points of GDP (Table 3 and Figure 4).

- Fiscal consolidation during 1992-95 relied, quite appropriately, on the compression of current expenditures - a cutback in personnel costs in 1993, and a progressive reduction in subsidies to enterprises and in operations and maintenance expenditure.

- $\quad$ The fiscal strategy envisaged since 1998 under the last two PRGF arrangementsnamely, achieving fiscal consolidation through higher revenue mobilization, reliant on continued enhancements in tax administration, while creating room for higher spending on priority areas for poverty reduction (viz., health, education, and social safety nets) - has not materialized. First, the reduction in the overall budget deficit since 1998 is explained by decreases in expenditure, both current and capital. Tax revenue did increase gradually, but from 2000 onward these gains were almost entirely offset by declining non-tax revenue. ${ }^{4}$ Second, expenditure on priority areas did not increase as a ratio to GDP and fell short of the budgeted level as well (Figures 5, 6, and 7).

\section{Tax revenue collections and foreign-financed capital expenditure have}

persistently underperformed. Since mid-1999, tax collections were being monitored under Fund-supported programs by way of quarterly indicative floors. These benchmarks were typically not met, except in 2000 . In four out of the six revenue shortfall years during 1998-2004, the shortfall exceeded 1 percent of GDP. The shortfalls were primarily in the areas of VAT, customs duties, and excise taxes (Table 4). Faced with the prospect of lower revenues, the government typically undertook cuts in operations and maintenance expenditures and in investment in order to remain within the domestic financing limit. In

\footnotetext{
${ }^{4}$ Profit transfers from the central bank to the budget fell from a peak of 4 percent of GDP in 1998 to about $1 \frac{1}{4}$ percent of GDP in 2003 . This mainly reflects sterilized intervention by the central bank in an environment of increasing capital inflows.
} 
Table 3. Albania : Government Revenues and Expenditures, 1992-2004

(In percent of GDP)

\begin{tabular}{|c|c|c|c|c|c|c|c|c|c|c|c|c|c|}
\hline & 1992 & 1993 & 1994 & 1995 & 1996 & 1997 & 1998 & 1999 & 2000 & 2001 & 2002 & 2003 & $\begin{array}{r}2004 \\
\text { Est. }\end{array}$ \\
\hline Total Revenue and Grants & 20.1 & 22.3 & 20.8 & 21.3 & 16.3 & 18.3 & 24.2 & 25.5 & 23.8 & 23.6 & 24.6 & 24.1 & 23.6 \\
\hline Total Revenue Excluding Grants & 15.2 & 19.1 & 18.8 & 20.3 & 16.2 & 17.6 & 22.5 & 22.7 & 22.7 & 23.0 & 23.9 & 23.7 & 23.3 \\
\hline Tax Revenue & 14.6 & 16.2 & 17.0 & 15.8 & 13.6 & 14.2 & 17.5 & 17.6 & 19.6 & 19.7 & 20.5 & 20.9 & 21.2 \\
\hline Tax revenues from Tax directorate and Customs & 11.6 & 13.8 & 13.7 & 10.9 & 8.4 & 10.1 & 13.6 & 13.6 & 15.6 & 15.6 & 16.0 & 16.2 & 16.3 \\
\hline Turnover tax / VAT & 3.9 & 3.6 & 2.3 & 2.2 & 2.9 & 4.9 & 7.0 & 6.3 & 7.2 & 7.0 & 7.3 & 7.3 & 7.4 \\
\hline Profit tax & 2.3 & 2.8 & 1.3 & 1.0 & 1.1 & 0.7 & 1.0 & 1.3 & 1.5 & 1.7 & 1.9 & 1.9 & 2.0 \\
\hline Excise tax & 2.1 & 3.1 & 4.6 & 4.6 & 1.6 & 0.7 & 1.2 & 1.5 & 1.7 & 1.6 & 1.5 & 1.8 & 2.1 \\
\hline Small business tax & 0.4 & 0.4 & 0.4 & 0.4 & 0.3 & 0.1 & 0.2 & 0.3 & 0.3 & 0.3 & 0.4 & 0.4 & 0.5 \\
\hline Personal income tax & 0.0 & 0.1 & 0.3 & 0.3 & 0.2 & 0.3 & 0.3 & 0.7 & 0.9 & 1.1 & 1.0 & 0.9 & 0.9 \\
\hline National taxes & 0.5 & 1.3 & 2.0 & 0.0 & 0.0 & 0.7 & 0.8 & 1.3 & 1.4 & 1.6 & 1.5 & 1.3 & 1.3 \\
\hline Customs duties & 2.5 & 2.5 & 2.9 & 2.5 & 2.4 & 2.8 & 3.1 & 2.4 & 2.6 & 2.2 & 2.1 & 2.0 & 1.7 \\
\hline Other & 0.0 & 0.0 & 0.0 & 0.0 & 0.0 & 0.0 & 0.0 & 0.0 & 0.0 & 0.0 & 0.2 & 0.6 & 0.3 \\
\hline Property and local taxes & 0.1 & 0.1 & 0.2 & 0.4 & 0.4 & 0.0 & 0.1 & 0.2 & 0.2 & 0.3 & 0.4 & 0.6 & 0.7 \\
\hline Other taxes & 0.0 & 0.0 & 0.0 & 0.9 & 0.7 & 0.0 & 0.0 & 0.0 & 0.0 & 0.0 & 0.0 & 0.0 & 0.0 \\
\hline Social insurance contributions & 2.9 & 2.3 & 3.0 & 3.7 & 4.0 & 4.1 & 3.8 & 3.8 & 3.8 & 3.8 & 4.1 & 4.1 & 4.2 \\
\hline Non-tax revenue: & 0.4 & 2.9 & 1.8 & 4.5 & 2.7 & 3.4 & 5.0 & 5.1 & 3.1 & 3.3 & 3.4 & 2.8 & 2.0 \\
\hline Profit transfer from $\mathrm{BOA}$ & 0.0 & 0.9 & 0.2 & 2.3 & 1.2 & 2.5 & 4.0 & 3.7 & 1.9 & 1.9 & 1.6 & 1.3 & 0.6 \\
\hline Income of budgetary institutions & 0.1 & 0.8 & 1.0 & 1.6 & 0.9 & 0.6 & 0.8 & 1.1 & 0.9 & 0.7 & 1.0 & 0.9 & 1.0 \\
\hline Other & 0.4 & 1.2 & 0.6 & 0.6 & 0.6 & 0.4 & 0.3 & 0.2 & 0.3 & 0.7 & 0.8 & 0.6 & 0.3 \\
\hline Grants & 4.9 & 3.2 & 2.0 & 1.0 & 0.1 & 0.7 & 1.6 & 2.8 & 1.0 & 0.6 & 0.7 & 0.4 & 0.3 \\
\hline Total Expenditure & 39.3 & 35.8 & 32.7 & 30.6 & 27.1 & 31.4 & 34.5 & 34.9 & 31.9 & 31.6 & 31.1 & 28.5 & 28.8 \\
\hline Current Expenditure & 35.6 & 27.4 & 24.7 & 23.0 & 23.1 & 27.1 & 28.7 & 27.1 & 25.3 & 24.2 & 24.6 & 24.2 & 23.3 \\
\hline Personnel cost & 9.0 & 7.2 & 7.3 & 7.3 & 7.3 & 7.9 & 6.9 & 6.5 & 6.6 & 7.0 & 6.7 & 6.4 & 6.5 \\
\hline Interest & 1.1 & 2.1 & 2.1 & 2.0 & 2.8 & 5.8 & 8.8 & 7.5 & 5.8 & 4.3 & 3.9 & 4.3 & 3.7 \\
\hline Operations \& maintenance & 8.6 & 5.4 & 5.0 & 4.8 & 3.9 & 4.2 & 4.5 & 5.0 & 4.4 & 3.9 & 3.3 & 3.2 & 2.8 \\
\hline Subsidies & 6.8 & 1.7 & 1.1 & 0.5 & 0.4 & 0.5 & 0.6 & 0.5 & 1.0 & 1.3 & 1.0 & 0.7 & 0.5 \\
\hline Social insurance outlays & 5.6 & 5.2 & 5.2 & 8.3 & 8.4 & 6.2 & 5.9 & 5.8 & 5.9 & 6.1 & 6.4 & 6.4 & 6.3 \\
\hline Local government expenditure & $\ldots$ & $\ldots$ & $\ldots$ & $\ldots$ & $\ldots$ & 0.1 & 0.2 & 1.7 & 1.4 & 1.6 & 1.9 & 2.1 & 2.1 \\
\hline Social protection transfers & $\ldots$ & $\ldots$ & $\ldots$ & $\ldots$ & $\ldots$ & 2.3 & 1.9 & 1.8 & 1.6 & 1.5 & 1.4 & 1.3 & 1.3 \\
\hline Other & 4.6 & 5.8 & 4.1 & 0.1 & 0.4 & 0.0 & 0.0 & 0.0 & 0.0 & 0.0 & 0.0 & -0.3 & 0.0 \\
\hline Capital Expenditure & 3.6 & 8.4 & 7.9 & 7.6 & 4.0 & 4.3 & 5.8 & 7.8 & 6.6 & 7.3 & 6.7 & 4.5 & 5.1 \\
\hline Domestically financed & 3.6 & 3.6 & 3.0 & 4.5 & 2.9 & 2.0 & 2.6 & 2.5 & 3.0 & 4.1 & 3.0 & 2.6 & 3.4 \\
\hline Foreign financed & 0.0 & 4.8 & 4.9 & 3.1 & 1.2 & 2.2 & 3.2 & 3.6 & 3.1 & 3.3 & 3.6 & 1.9 & 1.7 \\
\hline Cash Balance (including grants) & -19.2 & -13.5 & -11.9 & -9.3 & -10.8 & -13.1 & -10.3 & -9.4 & -8.2 & -7.9 & -6.6 & -4.4 & -5.3 \\
\hline Cash Balance (excluding grants) & -24.1 & -16.7 & -13.8 & -10.3 & -10.9 & -13.7 & -12.0 & -12.2 & -9.2 & -8.5 & -7.2 & -4.8 & -5.5 \\
\hline \multicolumn{14}{|l|}{ Sources of financing } \\
\hline Domestic & 18.7 & 8.7 & 7.3 & 5.9 & 9.8 & 11.2 & 7.2 & 5.8 & 4.9 & 5.3 & 3.3 & 3.0 & 4.1 \\
\hline Privatization receipts & 0.9 & 0.6 & 1.1 & 0.1 & 0.2 & 0.3 & 0.0 & 0.2 & 1.7 & 2.2 & 0.1 & 0.1 & 2.0 \\
\hline Net borrowing & 17.8 & 8.1 & 6.2 & 5.8 & 9.6 & 10.9 & 7.2 & 5.6 & 3.2 & 3.1 & 3.2 & 2.9 & 2.0 \\
\hline Foreign & 0.5 & 4.8 & 4.6 & 3.4 & 1.0 & 1.9 & 3.2 & 3.6 & 3.3 & 2.6 & 3.3 & 1.4 & 1.2 \\
\hline \multicolumn{14}{|l|}{ Memorandum items: } \\
\hline Primary Balance (including grants) & -18.1 & -11.4 & -9.8 & -7.3 & -8.0 & -7.3 & -1.6 & -1.9 & -2.4 & -3.6 & -2.6 & -0.2 & -1.6 \\
\hline Primary Balance (excluding grants) & -23.0 & -14.6 & -11.8 & -8.3 & -8.1 & -7.9 & -3.2 & -4.8 & -3.4 & -4.2 & -3.3 & -0.5 & -1.9 \\
\hline \multicolumn{14}{|l|}{ Expenditures by function } \\
\hline Health & $\ldots$ & $\ldots$ & $\ldots$ & 2.1 & 1.9 & 1.9 & 1.9 & 2.5 & 2.3 & 2.0 & 2.2 & 2.3 & $\ldots$ \\
\hline Education & $\ldots$ & $\ldots$ & $\ldots$ & 3.4 & 3.0 & 3.5 & 3.3 & 3.6 & 3.2 & 3.3 & 3.0 & 3.1 & $\ldots$ \\
\hline Social Security and welfare & $\ldots$ & $\ldots$ & $\ldots$ & $\ldots$ & $\ldots$ & 8.3 & 7.8 & 7.5 & 7.5 & 7.6 & 7.2 & 7.7 & $\ldots$ \\
\hline Social insurance outlays & $\ldots$ & $\ldots$ & $\ldots$ & $\ldots$ & $\ldots$ & 6.2 & 5.9 & 5.8 & 5.9 & 6.1 & 6.4 & 6.4 & $\ldots$ \\
\hline Social assistance & $\ldots$ & $\ldots$ & $\ldots$ & $\ldots$ & $\ldots$ & 1.3 & 1.5 & 1.3 & 1.3 & 1.2 & 1.2 & 1.1 & $\ldots$ \\
\hline Unemployment insurance & $\ldots$ & $\ldots$ & $\ldots$ & $\ldots$ & $\ldots$ & 0.7 & 0.4 & 0.3 & 0.4 & 0.3 & 0.2 & 0.1 & $\ldots$ \\
\hline
\end{tabular}


Figure 4. Albania: Fiscal Balance, 1993-2004

(in percent of GDP)
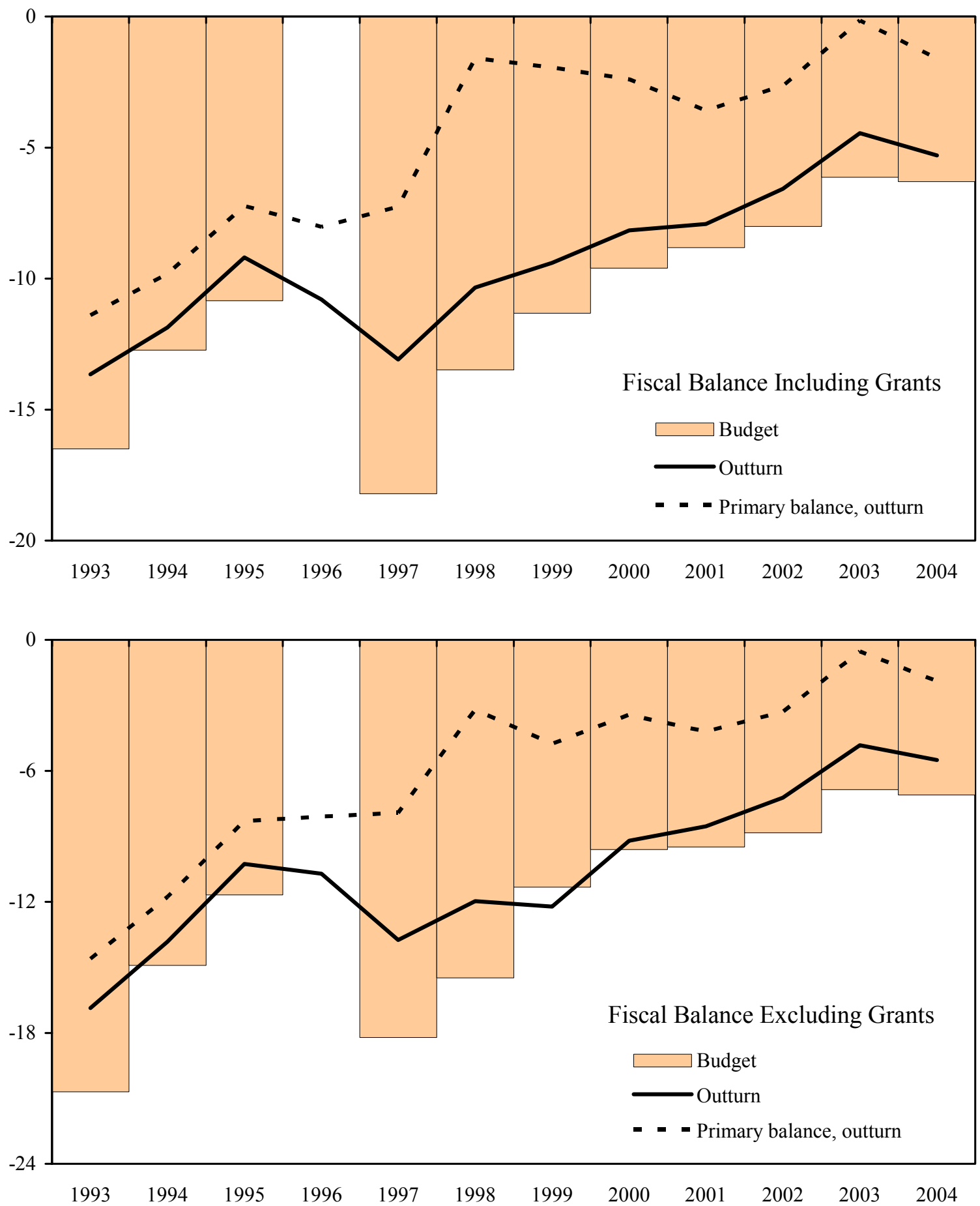

Sources: Data provided by Albanian authorities; and IMF staff reports.

1/ Budget figures for 1996 were not available. 
Figure 5. Albania: Government Revenue, 1993-2004 1/

(in percent of GDP)
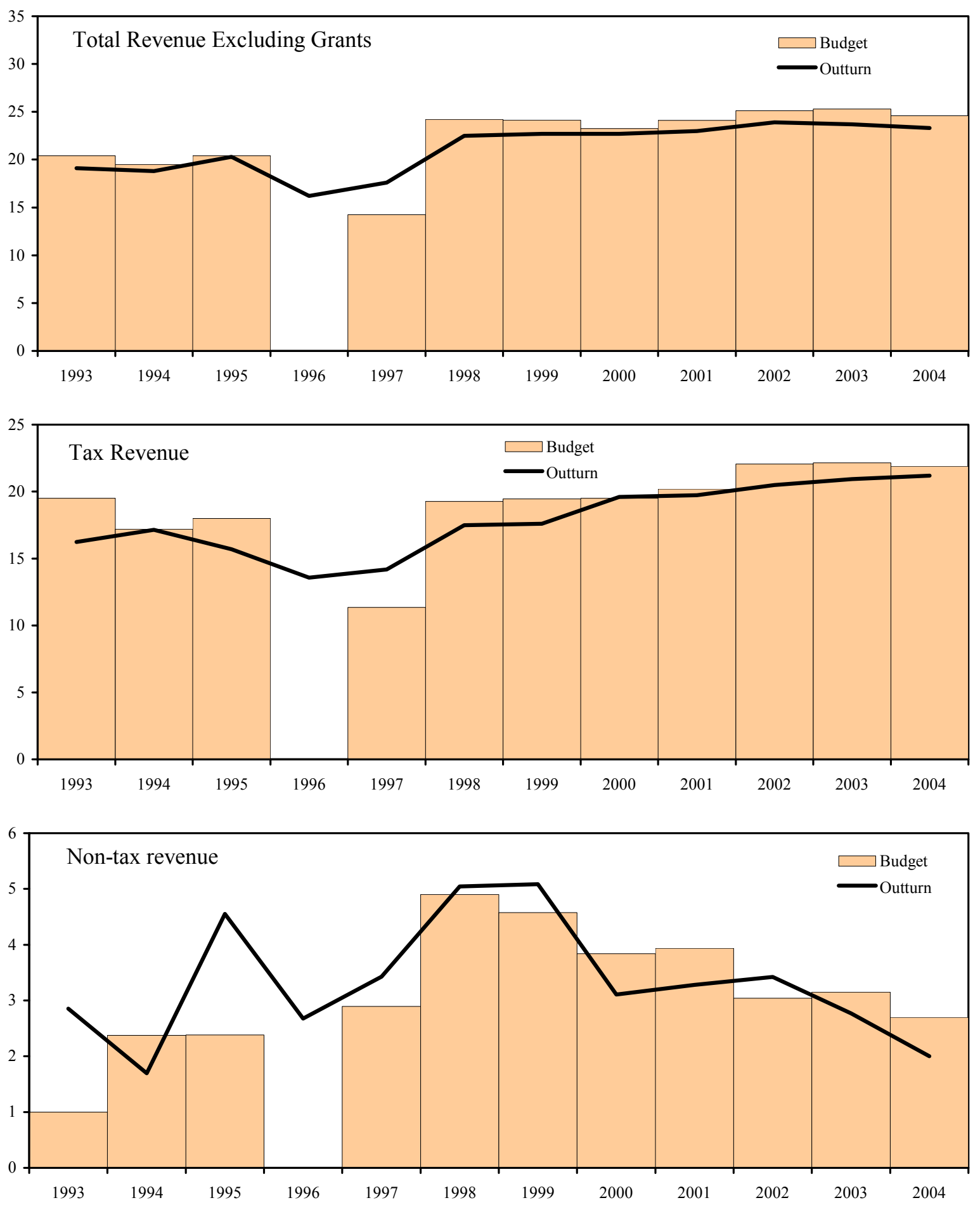

Sources: Data provided by Albanian authorities; and IMF staff reports.

1/ Budget figures for 1996 were not available. 
Figure 6. Albania: Expenditure Developments, 1993-2004 1/

(in percent of GDP)
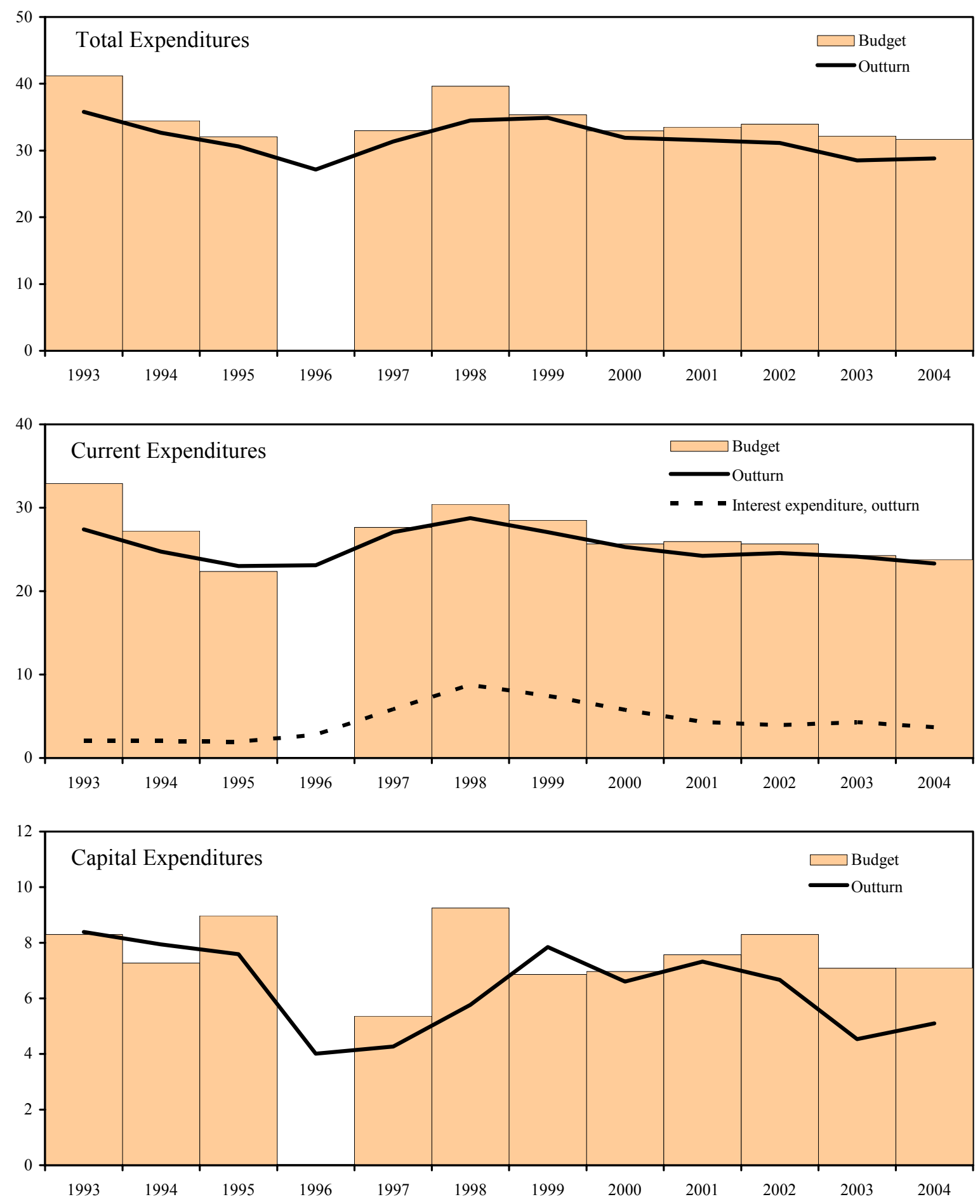

Sources: Data provided by Albanian authorities; and IMF staff reports.

1/ Budget figures for 1996 were not available. 
Figure 7. Albania: Expenditure on Priority Areas, 1998-2003

(in percent of GDP)
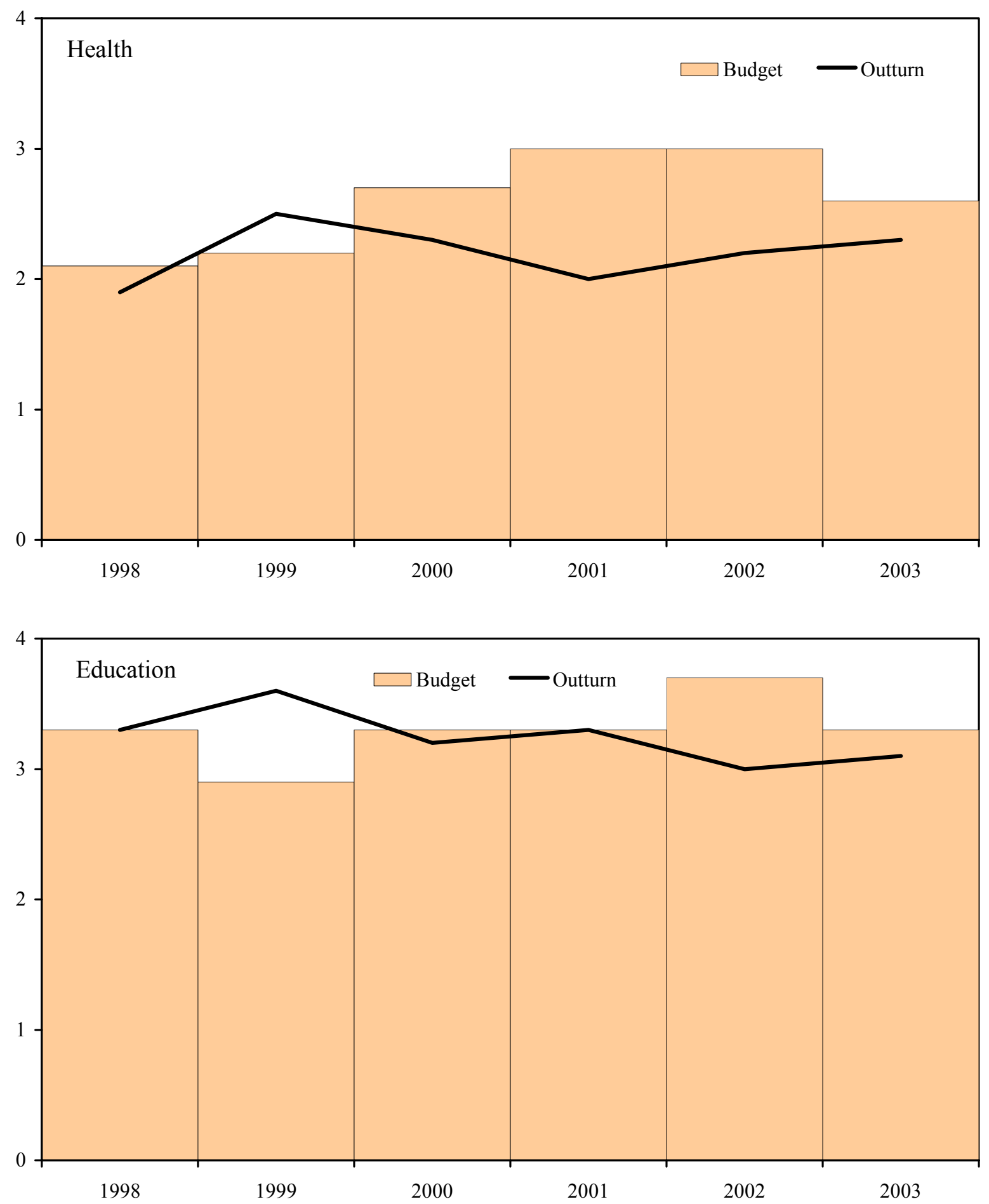

Source: IMF staff reports. 
Table 4. Albania: Deviations in Tax Collections from Budgeted Levels, 1998-2004

\begin{tabular}{|c|c|c|c|c|c|c|c|}
\hline & 1998 & 1999 & 2000 & 2001 & 2002 & 2003 & $\begin{array}{r}2004 \\
\text { Est. }\end{array}$ \\
\hline & \multicolumn{6}{|c|}{ (Deviation as percent of GDP) $1 /$} & \\
\hline $\begin{array}{l}\text { Total tax revenue } \\
\text { Of which: }\end{array}$ & -1.8 & -1.8 & 0.1 & -0.5 & -1.6 & -1.2 & -0.6 \\
\hline Value added tax (VAT) & -1.3 & -1.2 & -0.2 & -0.5 & -0.8 & -0.6 & 0.1 \\
\hline Excise taxes & -0.3 & 0.0 & 0.0 & -0.3 & -0.7 & 0.1 & 0.0 \\
\hline Customs duties & -0.6 & -0.7 & -0.1 & -0.1 & -0.2 & -0.1 & -0.1 \\
\hline Personal income tax & 0.1 & 0.1 & 0.2 & 0.1 & -0.1 & -0.1 & -0.2 \\
\hline Profits tax & 0.2 & 0.1 & 0.4 & 0.2 & 0.2 & 0.0 & 0.1 \\
\hline \multirow[t]{2}{*}{ Social insurance contributions } & 0.3 & -0.1 & 0.0 & -0.1 & -0.1 & -0.3 & -0.1 \\
\hline & \multicolumn{6}{|c|}{ (Collection as percent of budgeted level) } & \\
\hline \multicolumn{7}{|l|}{ Of which: } & 97.1 \\
\hline Value added tax (VAT) & 84.7 & 84.5 & 97.3 & 93.6 & 90.3 & 92.7 & 101.7 \\
\hline Excise taxes & 82.2 & 98.7 & 100.4 & 84.5 & 68.6 & 105.7 & 99.8 \\
\hline Customs duties & 83.2 & 78.2 & 97.1 & 93.6 & 89.7 & 94.4 & 92.6 \\
\hline Personal income tax & 127.0 & 114.6 & 122.2 & 106.0 & 93.2 & 86.3 & 82.8 \\
\hline Profits tax & 117.7 & 111.2 & 137.5 & 115.0 & 110.9 & 101.1 & 105.0 \\
\hline Social insurance contributions & 107.7 & 98.4 & 101.0 & 97.1 & 98.3 & 93.3 & 97.6 \\
\hline
\end{tabular}

Source: EPA team calculations.

1/ A negative sign denotes that actual collection was lower than the budgeted level. 
order to guard against haphazard cuts, budgets in the past few years incorporated contingency reserves, but these were not enough and spending cuts had to be identified. The ad hoc expenditure cuts and shortfalls in foreign financing were the main reasons for spending on priority sectors falling short of the budgeted levels.

23. The shortfalls in foreign-financed capital expenditure have been explained in Fund staff reports in terms of optimistic projections by the authorities, inadequate donor coordination, and procurement delays.

24. Fund staff reports ascribe blame for tax revenue shortfalls to ongoing weaknesses in customs and tax administration-owing to delays in reform, frequent managerial changes, and political uncertainties - but this view was only partly shared by the tax experts who had provided technical assistance to Albania in 2002-03. In their technical assistance reports, ${ }^{5}$ the tax experts observed that further improvements in revenue administration were indeed key to increasing tax collections in a sustainable manner over time. However, they also argued that: (i) revenue gains from improved administrative efficiency, including better compliance, built into the budget projections were overly optimistic, ${ }^{6}$ and that (ii) Albania's low revenue effort was overstated on account of its large agricultural sector. When expressed as ratio to nonagricultural GDP, revenue performance of indirect taxes in Albania was comparable with that in several central and east European transition countries (Table 5).

25. The authorities set ambitious revenue targets believing that it would lead to higher collections than otherwise, because of the increased incentives on the part of the tax collectors. Insofar as revenue collections have increased over time (see Figure 5), the authorities have a point. However, in the opinion of the tax experts providing technical assistance, the setting of unrealistic revenue targets had detracted attention from the reform efforts necessary for sustained revenue performance and had caused tax and customs officials to exert excessive pressure on a relatively small base of regular tax payers. ${ }^{7}$ Indeed, there is evidence in the governance literature that providing incentives to tax inspectors to collect

${ }^{5}$ Albania: Progress with Tax and Customs Administration Reforms, IMF Fiscal Affairs Department, November 2002; and Albania: Selected Issues in Tax Design, IMF Fiscal Affairs Department, February 2004.

${ }^{6}$ For example, the 2002 budget had assumed a 10-14 percent increase in revenue on account of improvements in tax administration, whereas the tax experts believed that a 5 percent gain could be reasonably expected in the absence of extraordinary circumstances.

${ }^{7}$ The November 2002 FAD technical assistance report noted anecdotal evidence of other perverse impact on the behavior of tax and customs officials that did not result in any net revenue gains for the tax department as a whole. For example, a consequence of revenue targets being distributed to the level of the Customs Houses was that individual offices were likely clearing goods at the border to meet revenue targets rather than having the goods transit inland for clearance. 


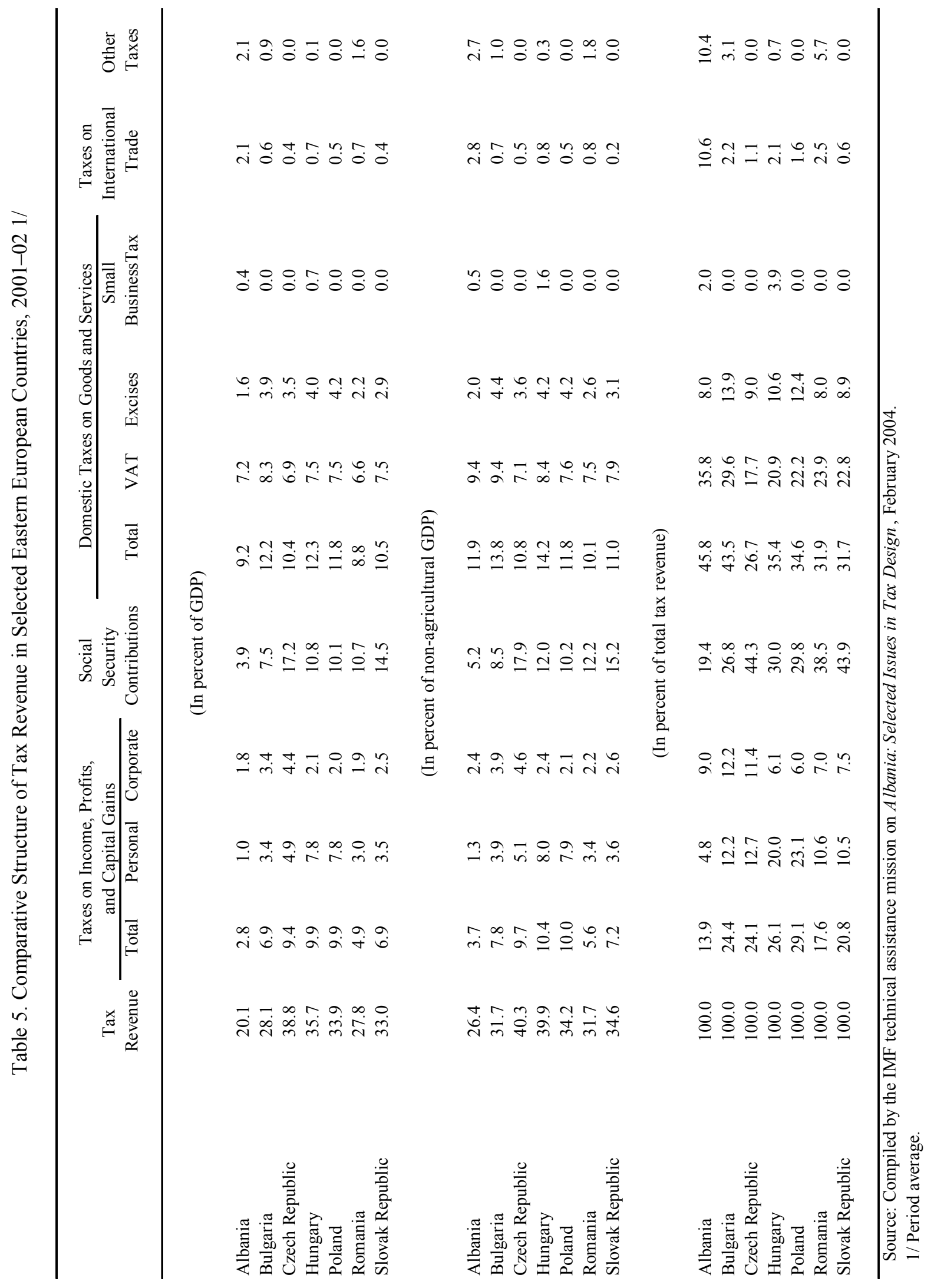


revenues more aggressively can result in undesired side effects in the absence of complementary administrative reforms. Harassment problems can be mitigated if tax administration is computerized, the information base is centralized, and there is an effectively functioning appeals court. These complementary organizational requirements were not fully in place in Albania when the incentive system for tax collection was introduced in 2000.

26. As the Fund staff team for Albania became aware of the considerations noted by the tax experts, it did propose more realistic revenue projections in the 2002-04 budgets, and called for specific supporting measures. But, the projections were clearly not scaled back sufficiently. The underperformance continued (see Table 4 and Figure 5). In the context of the preparation of the 2005 budget, the Fund staff has strongly reiterated the desirability of realistic budget revenue projections since there were indications of the authorities being reluctant to scale back ambitious targets as they felt that the budget would otherwise be difficult to pass through parliament because of the implications for spending.

27. With the prospects for revenue gains from enhancements in tax administration looking more limited than had been projected earlier under the Fund-supported programs, expenditure prioritization and improved expenditure management become crucial requirements for preserving spending on priority areas. Whereas the authorities have made notable progress in containing personnel cost while improving public sector salaries, public expenditure management in general has lagged, as noted below.

- $\quad$ Personnel costs in the budget declined from 9 percent of GDP in 1992 to about $6 \frac{1}{2}$ percent of GDP in 2004. Steady reductions in staffing levels in budgetary institutions - by about one half overall during 1992-2003 - created room for general wage increases and for increased differentiation in public sector salaries considered necessary for tackling the problem of high turnover of skilled staff and poor governance. Average real wages in the budgetary sector increased three fold during 1993-2003 and nearly doubled during 1998-2003. According to an ongoing World Bank project, by 2002, the salaries of those in the civil service, including sector chiefs and specialists, had come up to par with salaries of their private sector comparators (Tables 6 and 7). ${ }^{8}$

- Progress in computerizing treasury operations and debt management has been slow, and these tasks are still performed manually for the most part. According to World Bank staff, who have taken the lead in the policy dialogue in this area, efforts to modernize the financial management system have been pushed along as rapidly as has been feasible, given the government's absorptive capacity constraints. This being the case, perhaps these efforts should have started earlier. Efforts are in the early

\footnotetext{
${ }^{8}$ Public Administration Reform Project (IDA Credit No. 3328-ALB).
} 


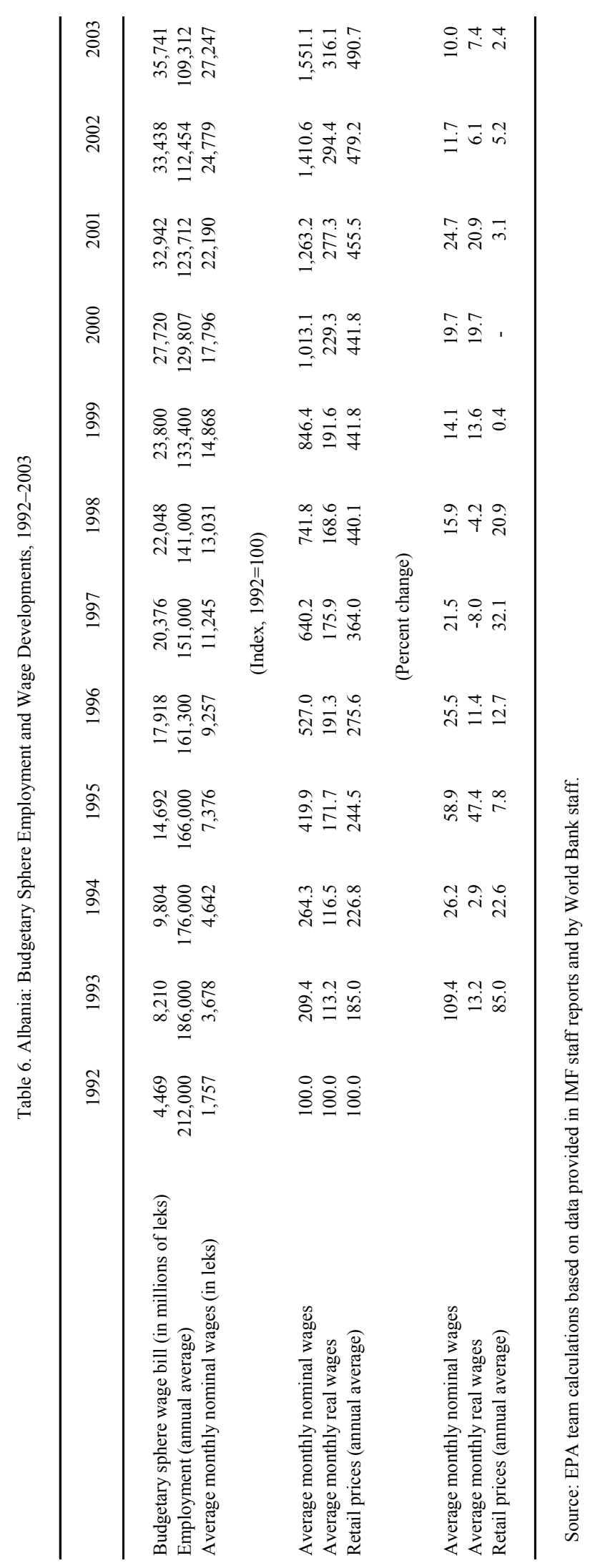


Table 7. Albania: Public Sector Salaries Relative to Private Sector

\begin{tabular}{|c|c|c|c|c|c|}
\hline & 1998 & 1999 & 2000 & 2001 & 2002 \\
\hline $\begin{array}{l}\text { Ratio of average central government wages to } \\
\text { average enterprise wages }\end{array}$ & 1.92 & 1.88 & 2.24 & 2.42 & $\ldots$ \\
\hline $\begin{array}{l}\text { Ratio of average salary of chief of sector in } \\
\text { public sector to average salary of middle level } \\
\text { manager in private sector }\end{array}$ & $\ldots$ & $\ldots$ & 0.41 & 0.44 & 1.04 \\
\hline $\begin{array}{l}\text { Ratio of average salary of specialist in public } \\
\text { sector to average salary of non-financial } \\
\text { management specialist in private sector }\end{array}$ & $\ldots$ & $\ldots$ & 0.62 & 0.67 & 1.06 \\
\hline
\end{tabular}

Source: World Bank staff. 
stages to enhance the accountability of all budgetary institutions and to strengthen the capacity of both line ministries and ministry of finance for strategic planning and management of public investment, including externally-financed projects. There is still some way to go in synchronizing the annual budget, the Medium-Term Budget Program, and the National Strategy for Socio-Economic Development. Policy coherence and coordination among the lead agencies involved in the reform process are ongoing challenges.

28. Finally, given the persistent over performance on the macroeconomic front, might the Fund-supported programs have accommodated a more relaxed fiscal stance, which could have provided more domestic resources for anti-poverty spending? With the benefit of hindsight, the answer appears to be yes. As noted earlier in paragraph 14, macroeconomic performance was better than program expectations. Further, private remittance inflows - a key element of private national saving - also were virtually always larger than projected in all Fund-supported programs, and concerns about their likely decline proved unfounded (Table 8 and Figure 2). Thus, the risks to fiscal and external sustainability have turned out to be more moderate than assessed by the Fund staff when setting the fiscal deficit targets. On the other hand, it should be recognized that data weaknesses hampered the staff in monitoring developments, in making macroeconomic projections, and in policy formulation. Further, the fiscal deficit, though declining, was running at a fairly high level for much of the period. Under these circumstances, targeting a conservative fiscal policy stance is understandable.

\section{The Monetary Framework}

29. The Bank of Albania (BoA) has followed an eclectic approach to monetary management within a flexible exchange rate regime, guided by the monetary program drawn up in consultation with the Fund staff. In recent years, the BoA also has publicly announced its informal inflation target of 2-4 percent with the aim of anchoring expectations and encouraging policy discipline. This approach has served Albania well in bringing down inflation and keeping it low, and the BoA has gained credibility as the guardian of price stability. The BoA has considerable legal and operational independence.

30. The adoption of a flexible exchange rate regime at the beginning of transition was influenced by the lack of a reserve cushion and the uncertainties of transition. This regime proved particularly invaluable during the pyramid scheme crisis, enabling the BoA to preserve its foreign exchange reserves essentially intact. A flexible regime was retained after the crisis. A change in the nominal anchor was felt unnecessary, as it would not buy much in the way of policy credibility and because high and sticky inflationary expectations were not considered to be a problem in Albania.

31. Within a flexible exchange rate regime, the BoA has intervened periodically on a temporary basis to smooth exchange rate fluctuations without affecting underlying trends. The lek appreciated steadily for a while since mid-1997, driven by large inflows of 


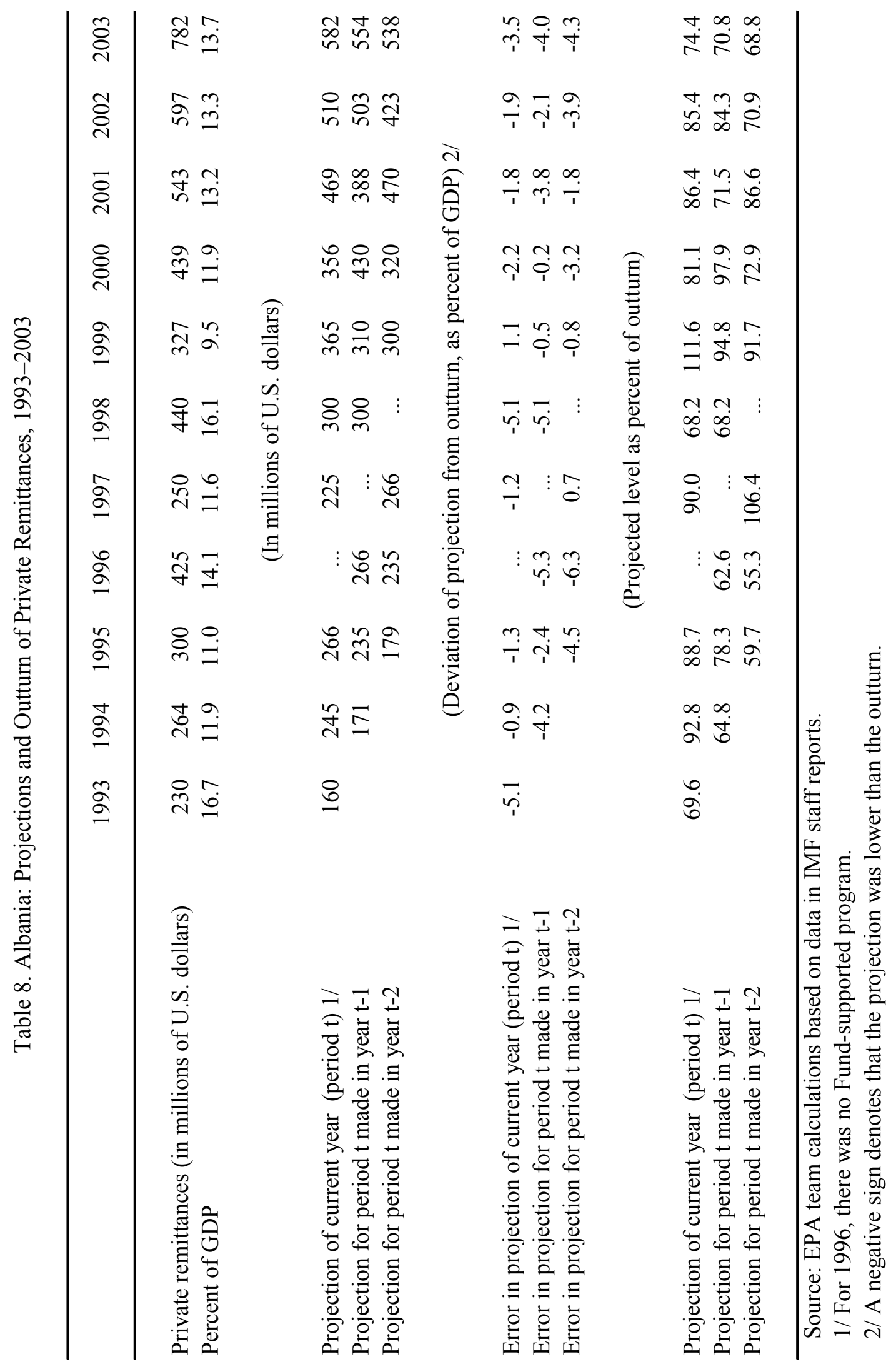


official assistance and private remittances. However, since early 2002, there has been little cumulative appreciation both vis-à-vis the euro and on a nominal effective basis. With relative price differentials with the main trading partners exhibiting a flat trend, the real effective exchange rate has moved in line with the nominal effective exchange rate (Figure 8). Against the backdrop of Albania's weak export performance, the question arises whether real exchange rate appreciation has created a competitiveness problem. Fund staff analysis during the 2002 Article IV consultation concluded that the effect of exchange rate appreciation on exports has likely been limited and that export performance has likely been impaired by non-price factors. ${ }^{9}$ Developments in the exchange rate and the relevant nonprice factors since 2002 (see paragraphs 39-40), do not seem to call for any modification of these conclusions.

32. The conduct of monetary policy operations has become more refined over time. During the 1990s, the BoA relied on bank-by-bank credit ceilings and kept minimum deposit rates positive so as to induce growth in domestic currency deposits. Following extensive technical assistance from the Fund to create the pre-conditions-developing the instruments and strengthening bank supervision - the BoA switched to indirect tools of monetary management in mid-2000, with repo auctions becoming the key policy instrument for controlling bank liquidity. The floors on deposit rates were also removed. However, because monetary transmission in Albania is poorly understood - in the absence of a meaningful credit channel and with widespread dollarization - efforts to manage inflation directly are still supported by indirect targets for net domestic assets and net international reserves. The BoA's aim is to move to formal inflation targeting over the medium term. Accordingly, it has initiated steps to strengthen its analytical capacities, with technical assistance from the Fund.

\section{Selected Dimensions of Structural Policies}

\section{Financial sector reform}

33. The pyramid scheme crisis in early 1997 symbolized the most costly policy failure on the part of the authorities and, to some degree, weak Fund surveillance. Delays in fundamental reform of the banking system, and the consequent imposition of tight controls on bank credit, contributed to the emergence of an active informal money market. The failure of the government to implement its own laws and regulations allowed the pyramid schemes to mushroom to enormous proportions. Significantly, there was no reference to the growth of unauthorized banking activities in any Fund staff report for Albania before the 1996 Article IV consultation report that was issued in February 1997. According to that report and another Fund staff study, ${ }^{10}$ it was not until August 1996, when

\footnotetext{
${ }^{9}$ Box 2 in the Staff Report for the 2002 Article IV consultation and the First Review under the PRGF (IMF Country Report No. 03/63, March 7, 2003).

${ }^{10}$ Christopher Jarvis, "The Rise and Fall of the Pyramid schemes in Albania,” IMF Working Paper, WP/99/98, July 1999.
} 
Figure 8. Albania: Exchange Rates, 1994-2004
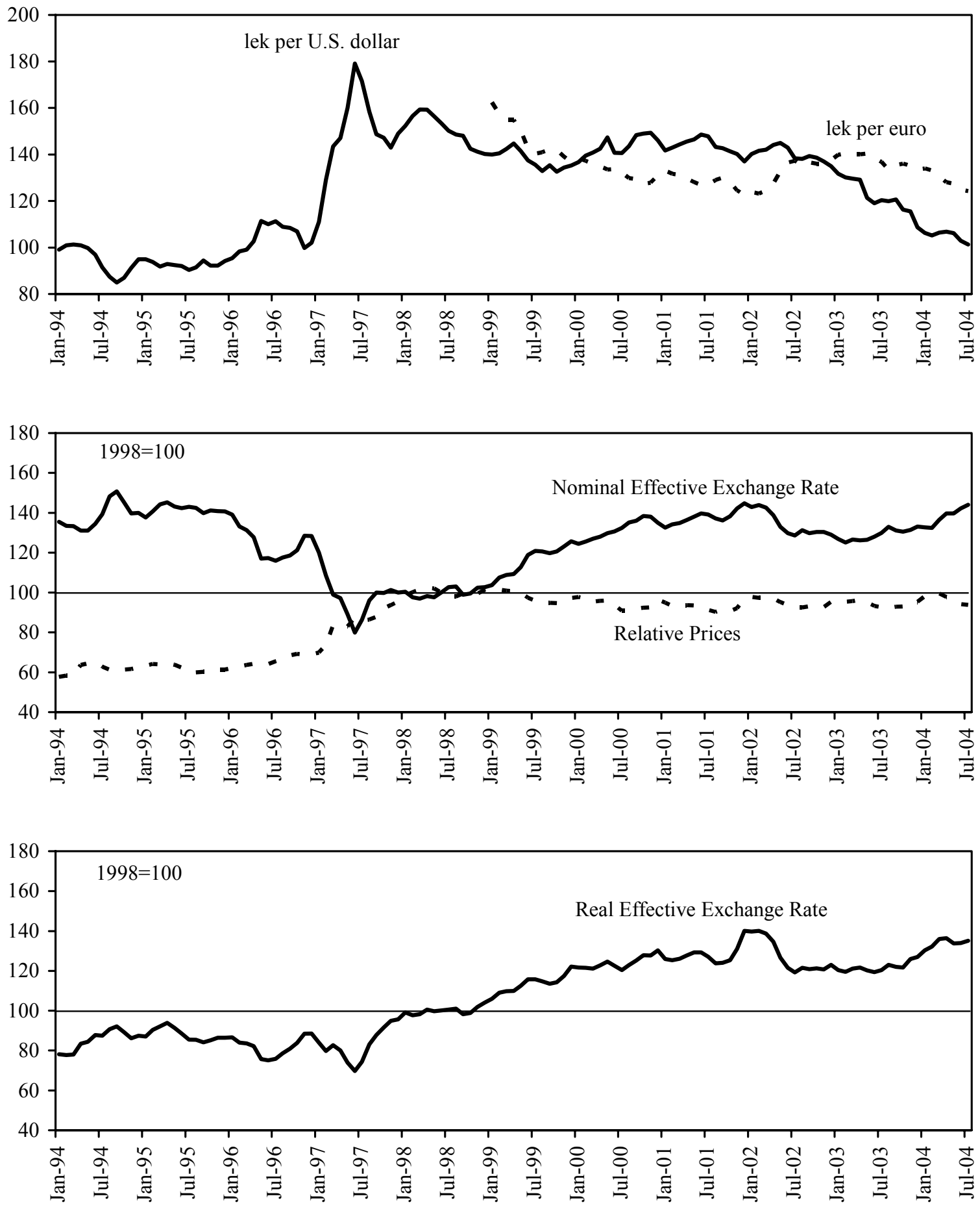

Sources: International Financial Statistics (IFS); and Fund staff estimates. 
the true nature of the schemes became increasingly apparent, that a strong warning was given by the Fund staff and this was followed by a further warning from Fund management in October. However, these warnings were not heeded by the authorities. Even at the time of the Article IV mission in mid-November 1996, on the eve of the collapse, the Fund staff were able to discuss the risks posed by the proliferation of financial pyramid schemes only in the abstract. $^{11}$

34. A comprehensive strategy to reform the commercial banking system began only in early 1995- three years into the Fund's engagement in Albania-as evidence mounted that the state-owned banks were not capable of effective financial intermediation in a market-oriented environment. In the early years of transition, all three state-owned banks had serious managerial and accounting problems, poor credit evaluation, and lackluster follow up on overdue loans. To complicate matters, the custom of nonpayment of loans to state-owned banks was entrenched and procedures of the legal system had made loan recovery very difficult. Thus, more than one fourth of all credit granted since the reorganization of the banking system in mid-1992 was in the non-performing category by end-1994. The restructuring efforts undertaken during 1995-96 - an initial cleaning up of balance sheets, change in management, and a branch rationalization program - did not have much success in repairing the efficiency and financial health of the state-owned banks. At end-1996, on the eve of the pyramid scheme crisis, all three state-owned banks were insolvent.

\section{Following the pyramid scheme crisis, the focus shifted toward privatizing the}

banks. The authorities heeded the Fund staff's advice on avoiding ambitious restructuring plans to increase the banks' net worth. The Rural Commercial Bank, the most flagrant bad lender among the three state-owned banks, was liquidated ahead of schedule in March 1998. The restructuring and privatization of the other two banks took longer than was envisaged. The National Commercial Bank (NCB) was transferred to foreign investors in November 2000. After an unsuccessful attempt in the first half of 2002, despite extensive marketing efforts with assistance from the International Finance Corporation, the Savings Bank was eventually privatized in early 2004 - four years past the target date first specified as a structural benchmark under a PRGF arrangement.

36. The delays in bank privatization were beyond the control of the authorities, but they did not have any negative fall-out, unlike in the early stage of transition. The sales were being sought under difficult conditions - the NCB around the time of the Kosovo crisis and the Savings Bank under a weak global market environment. Under these circumstances, the privatization timetable, supported by Fund conditionality, was perhaps too ambitious. The authorities ought to be given credit for persevering with the chosen strategy and for taking steps in the interim to safeguard the soundness of the two banks: while awaiting privatization, both banks were placed under the supervision of foreign advisors and were

\footnotetext{
${ }^{11}$ See Staff Report for the 1996 Article IV Consultation, paragraph 1 (see www.imf.org).
} 
restricted from any new lending. In parallel, the authorities initiated measures to strengthen the bank supervision and regulatory framework.

\section{Enterprise sector reform}

37. Enterprise privatization proceeded more slowly than expected but has been largely completed, except for a few strategic companies. In the early years of transition, many small- and medium-sized enterprises (SME) were privatized through auctions. For the larger enterprises that were more difficult to privatize, a mass privatization program was introduced in 1995, but the process came to a halt in 1996, in part because of restitution claims. The privatization program was reactivated in 1998, but implementation fell continuously short of targets set under Fund-supported programs. The causes of the delays were many: domestic political tensions, poor coordination among ministries, unresolved financial and legal disputes, uncertainties caused by the Kosovo crisis, and lack of investor interest. The privatization of the fixed-lines telecommunications company and the oil sector has experienced significant delays - the original deadlines were end-1998 and end-2000, respectively - and still remains outstanding. Against the backdrop of poor management and improper pricing, the delays in restructuring and privatization came at a cost: the large stateowned enterprises accumulated a huge stock of inter-enterprise arrears. ${ }^{12}$ There are no analytical studies on the impact of privatization on enterprise performance in Albania, but anecdotal evidence suggests that the loss of domestic inter-linkages that existed prior to privatization and competition from imports resulted in the demise of many SMEs; those that had links with foreign firms flourished.

38. Failure to address the problems in the electricity sector in a timely manner had an important bearing on the growing power shortages, posing a threat to growth and macroeconomic stability, but with reforms in the electricity sector now back on track the energy situation has begun to improve. Chronic failure to address the problem of illegal use and nonpayment, together with below-cost prices, encouraged excessive demand for electricity, and led to the suspension of World Bank credit and other donor support for power projects in 1998. The power supply situation deteriorated from 2000, owing to poor hydrological conditions, necessitating increased electricity imports and budget subsidies of about $1 / 4-1 / 2$ percent of GDP annually. Recognizing the magnitude of the power crisis and its wide-ranging macroeconomic and social implications, the authorities began implementing a rolling action plan for the restructuring of the electricity sector in 2001, and the Bank and donor community resumed their support once the commitment of the authorities was visible. Some of the action plan measures were supported by Fund conditionality, which kept up the pressure for implementation. The quarterly targets under the action plan for reducing nontechnical losses and improving bill collection rates have been consistently met - reflecting progress in installing meters, enforcing disconnection of nonpayers, and in organizational improvements in the electricity company. These measures, together with annual tariff

\footnotetext{
${ }^{12}$ At end-2001, these arrears amounted to the equivalent of 3.2 percent of GDP.
} 
adjustments since 2002, restored the electricity company to profitability in 2004, which will facilitate the planned elimination of subsidy for electricity imports from 2005 . The close oversight of an inter-ministerial committee and the coordinated approach adopted by the donors were important factors behind the progress in electricity sector reforms thus far.

\section{Governance issues}

39. Progress in improving the overall business climate has been slow. The 2002 Business Environment and Enterprise Performance Survey (BEEPS) found that little improvement was achieved in reducing corruption and improving standards of the judiciary since the first BEEPS was undertaken in 1999. In 2004, Albania ranked $108^{\text {th }}$ out of 145 countries in the Transparency International Corruption Perceptions Index with a score of 2.5 - on a scale of 0 (highly corrupt) to 10 (highly clean) — unchanged from the score received in the previous two years. In its March 2004 annual report and, more recently, in the context of the negotiations on a Stability and Association Agreement with Albania, the European Union expressed concern about insufficient progress in law enforcement and the fight against organized crime and corruption. The World Bank's ongoing operations on improving governance in Albania have focused on a wide array of legal and judicial reforms as well as on measures to depoliticize personnel management practices, to limit the scope for corruption by reducing discretion and ensuring clear and consistent regulations, and to require declaration of assets and financial holdings by public and elected officials.

40. Weaknesses in governance and inadequate infrastructure have stymied a broadbased and export-driven economic expansion. In the first years of transition, growth reflected supply response in agriculture and trade to reform measures. However, during the past five years, growth has been focused on construction and services, supported by large inflows of private remittances. Industry and other tradable sectors have not yet taken off. As highlighted in a 2003 report by FIAS, domestic and foreign investment in these sectors is hindered by administrative barriers - reflecting general weaknesses in governance and law enforcement, and abuse of power by government officials. The initial surge in agricultural growth was not sustained as the frequent absence of secure tenure or clear property titles has hampered development of a functioning land market and impeded investment in this sector; the property restitution law approved by Parliament in July 2004 is expected to remove this obstacle.

\section{Benefits of Fund Support, Conditionality, AND BANK-Fund Collaboration}

41. Besides providing a policy framework and financing, the Fund arrangements played a key role in catalyzing financial support from other multilateral agencies and the donor community, and in mobilizing internal support for reforms. The share of Fund resources in Albania's total financing requirements declined over time, especially under the current PRGF arrangement. Fund-supported programs provided the basis for significant balance of payments support from other multilateral and bilateral sources and for three Paris Club reschedulings (Table 9). Fund support also facilitated internal political consensus on 
appropriate policies. For the most part, policy slippages arising from political uncertainties or cracks in ownership were temporary. However, as noted earlier, there were two occasions (viz., 1996 and 2001-02) when the political uncertainties were prolonged or the environment was not conducive to consensus on reforms and enactment of cautious macroeconomic policies, and the Fund disengaged from a program mode.

\section{Structural conditionality under Fund arrangements was extensive, and} addressed areas critical for achieving program objectives. As discussed earlier in paragraph 18, conditionality increased policy focus and internal support, and did not appear to undermine program ownership. Even after the new guidelines on streamlining conditionality were put in place in 2002 , the number of conditions, though fewer, remained large - a reflection of the enormous structural agenda. The measures covered by conditionality can be classified into the following main categories: fiscal management and control, payments discipline, budgetary implications of enterprise reforms, financial sector reform, privatization, and - in the early years of transition - price and trade liberalization. Since mid-2003, Fund-supported programs have included a range of conditions supporting the strengthening of governance - in particular, relating to fiscal policy. There was considerable reliance on prior actions in structural conditionality; about one fourth of the structural measures were required as prior actions for program approval or completion of program review.

\section{There was close cooperation between the Fund and World Bank on matters} relating to structural reforms in Albania. The Bank played a lead role in policy dialogue in several areas with significant macroeconomic impact. These included financial sector reforms, power sector reforms, social sector and pension reforms, as well as public expenditure management and public administration reforms. The measures worked out between the authorities and the World Bank in these areas were incorporated into the Fundsupported programs on a selective basis. This approach successfully increased pressure on the authorities to maintain momentum. The overlap in conditionality decreased with the introduction of the new guidelines on streamlining conditionality in 2002. Notably, conditionality on land market reform and employment in budgetary institutions were dropped from Fund-supported programs, while that on public expenditure management was limited to measures for improving budget control of foreign-financed projects and state-owned enterprises. This streamlining of conditionality did not have any adverse effect on the achievement of programmed macroeconomic adjustment. In general, there was little friction between the Fund and Bank staff in reaching a consensus on the timing and details of reforms in the overlapping areas of interest.

44. The record on meeting program conditionality was on the whole good. The standard quantitative performance criteria (PCs) and benchmarks were always met, though the quarterly indicative targets on revenue collection were persistently missed, except in 
Table 9. Albania: Sources of External Financing, 1992-2003

\begin{tabular}{lrrr}
\hline & $1992-95$ & $1997-2001$ & 2002-03 \\
\hline Total financing requirement & 1,511 & 1,962 & 1,551 \\
$\quad$ (in millions of U.S. dollars) & & & \\
& (in percent of total financing requirement) \\
Sources of Financing & & & \\
IMF Disbursements 1/ 2/ 3/ & 4.2 & 3.7 & 1.0 \\
Official grants & 63.4 & 27.7 & 17.9 \\
Official medium- and long-term loans & 15.8 & 18.6 & 15.1 \\
Balance of payments support & 4.4 & 10.0 & 3.2 \\
Debt rescheduling & 33.2 & 9.3 & 18.2 \\
Foreign direct investment & 15.3 & 24.6 & 20.2 \\
Other 4/ & -36.3 & 6.1 & 24.5 \\
& & & \\
\hline
\end{tabular}

Source: EPA team calculations based on data in IMF staff reports.

1/ For 1992-95, SBA and ESAF arrangements.

2/ For 1997-2001, support under Emergency Post-Conflict assistance policy, and ESAF/PRGF arrangement.

3/ For 2002-03, PRGF arrangement.

4/ Includes errors and omissions, which were negative in 1992-94. 
2000. Measures subject to prior actions and structural PCs were implemented on a timely basis for the most part. In the majority of instances when the PCs were not met, the measures were converted to prior actions for the completion of program review. ${ }^{13}$ The record in achieving structural benchmarks was weaker, with delays being experienced, particularly in the areas of tax and customs administration and privatization (Table 10).

\section{The delays in satisfying structural conditionality in some areas raise questions} about the underlying causes and the content. The experience seems to suggest that, although political uncertainties and cracks in ownership did play a role, delays were more a reflection of organizational capacity constraints and a somewhat overambitious timetable. The FAD technical assistance reports identified inadequate staffing at the headquarters of the tax and customs departments and limited number of officials working directly on reform projects as having a direct bearing on the pace of reform implementation. To address this problem, structural benchmarks were established on recruiting additional staff under the current PRGF arrangement, but job training and skill upgrading still remain major development needs. In the case of privatization of banks and strategic enterprises, establishment of ambitious performance targets against a background of weak market environment and political risks that kept potential investors away can be questioned. In particular, the prior action on announcing the tender for privatizing Albtelecom - the fixedlines telephone company - in January 2002 seems to have been premature in that balance sheet problems still had to be addressed. ${ }^{14}$ When the privatization attempt failed, because of lack of buyer interest, new structural benchmarks were established on settling Albtelecom's financial and legal disputes. It is particularly striking that the timetable for the implementation of these benchmarks was extended several times before the conditionality was eventually dropped in 2004. As noted before, Albtelecom is still in state hands.

\section{Albania has received extensive technical assistance (TA) from the Fund to} strengthen economic policy design, develop implementation capacity, and improve compilation of statistical data, and the record on implementation of the recommendations is relatively positive. Still, as noted on a continued basis in Fund staff reports, further institutional development is required in virtually every sector. In the fiscal, monetary, and financial sectors, Fund technical assistance missions provided conceptual advice on reforms that were then implemented by the authorities, often with the assistance of long-term resident advisors supplied by the Fund and other providers. In areas related to central banking operations and financial sector regulation and supervision, skill transfer from resident experts took place effectively. However, in some tax and customs administration

\footnotetext{
${ }^{13}$ One notable exception was the PC on announcing tender for privatization of the Savings Bank by endNovember 2000. This was postponed to a later date, and not converted to a prior action.

${ }^{14}$ Indications are that both the authorities and Fund staff relied on the assessment of the foreign privatization advisor that the financial disputes of Albtelecom were not serious and, accordingly, agreed with the advisor's recommendation to announce the tender for Albtelecom.
} 


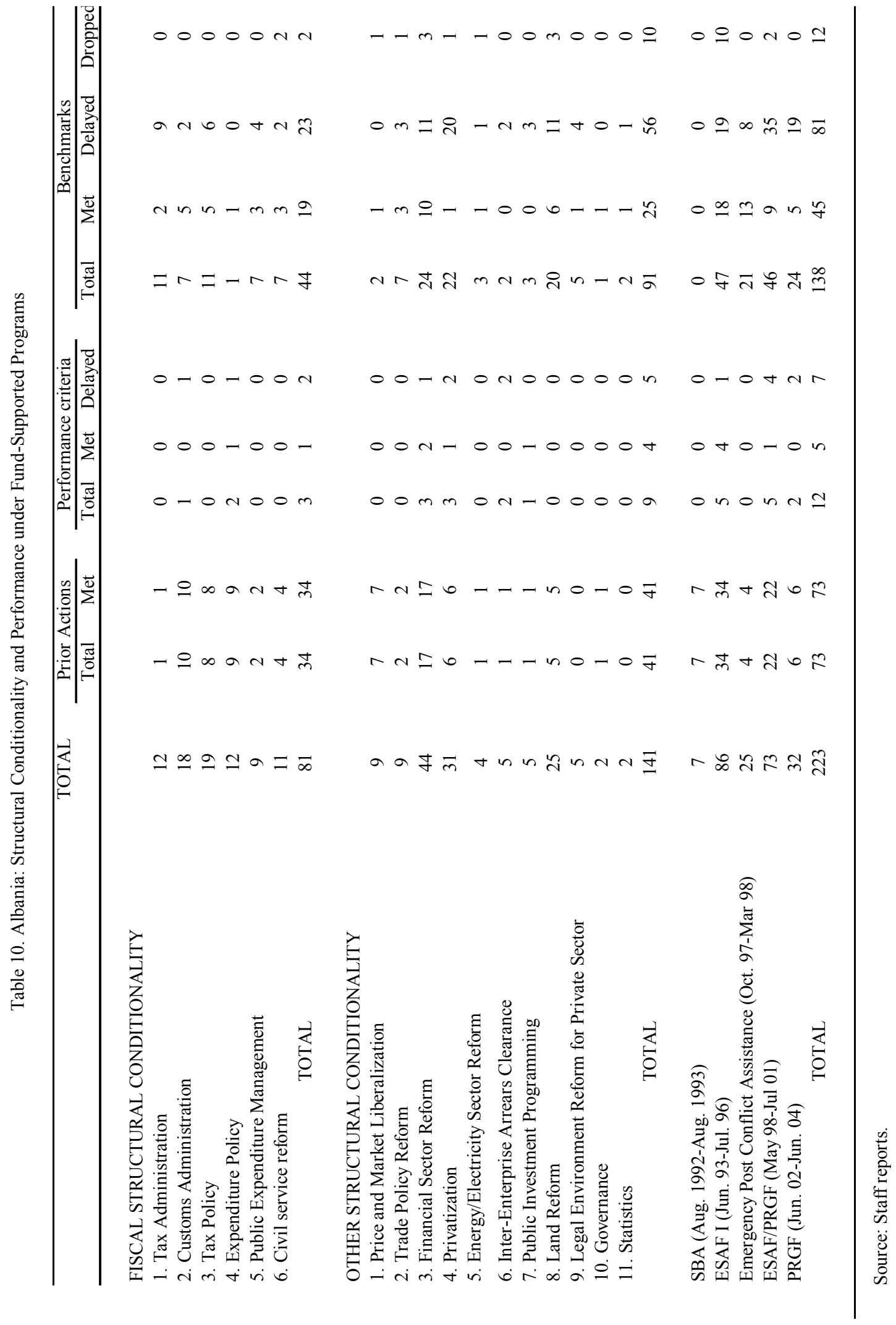


projects supported by other TA providers, foreign advisors stepped into the role of managers to compensate for weaknesses in administrative capacity. While this may have helped implementation, the transfer of skills was limited or slow. This increases the risk of the authorities falling into the trap of relying on supposedly transitional institutional capacities for implementing reforms as a permanent substitute for the regular public administration. Another problem experienced in a few projects in the fiscal area involving other multiple providers of TA was that of conflicting advice, thereby causing delays in implementation. With regard to TA on legal reform, the involvement of multiple providers has resulted in Albania adopting laws modeled on different jurisdictions with the continental legal system as well as on different models within the Anglo-American legal tradition. Together with the vast amount of legislation, this has led to difficulties in interpretation and implementation. ${ }^{15}$

\section{Considerations for Future Program Engagement}

\section{Present conditions do not seem ripe for the Fund to exit from a program mode} with Albania. The longer-term engagement of the Fund in Albania reflects particularly unfavorable starting conditions at the beginning of transition and an extensive structural reform agenda against the backdrop of deep administrative capacity constraints. There is no indication thus far that the Fund's program engagement led to reform fatigue - one of the concerns in the case of longer-term program engagement. On the contrary, the authorities clearly have been receptive to the Fund's policy advice, and program ownership has been solid overall. Although the prospective balance of payments financing needs appear to be limited, there are important macroeconomic challenges ahead and the structural reform agenda remains unfinished. It is evident from the discussion in Sections III and IV that continued capacity building in the budget formulation process, revenue mobilization, expenditure management, and governance is paramount. In this setting, there is considerable risk that the authorities may not be able to effectively formulate and implement the policy framework on their own.

\section{A few macroeconomic challenges will need careful handling in the period ahead.}

- Monetary management and financial supervision will face new demands as the scope for bank credit to the private sector expands with the recent privatization of the Savings Bank. Following its privatization, the Savings Bank is no longer restricted from new lending and is likely to diversify its portfolio away from government securities toward loans to enterprises and households. ${ }^{16}$ This, combined with the need for more extensive reliance on open market operations for monetary management, could put upward pressure on interest rate on treasury

\footnotetext{
${ }^{15}$ See Albania Beyond the Crisis: A Strategy for Recovery and Growth, World Bank Report No. 18658-ALB, December 7, 1998.

${ }^{16}$ The Savings Bank currently holds about 72 percent of the outstanding stock of treasury bills.
} 
bills, with implications for the government's debt service costs. Also, with the growing competition in the banking system, there is a risk of deterioration in the credit portfolios.

- Moving forward with the Stabilization and Association Agreement with the European Union (EU) will involve, inter alia, further reduction of tariffs, and a consequent loss of budgetary revenues. Compensating fiscal measures will have to be put in place in order to avoid a widening of the fiscal deficit.

- With Albania's current per capita income (US\$1,740) estimated at almost twice the cutoff level for IDA eligibility (US\$895), the availability of concessional external financing is expected to decline in the period ahead. In this setting, it would be important to ensure that non-concessional borrowing to finance infrastructure needs did not endanger fiscal and external viability. Further, accessing international financial markets would expose Albania to the vagaries of market sentiment.

- The structure of the external sector remains weak, with private remittances being the largest source of foreign exchange earnings, significantly exceeding the sum of merchandise exports and tourism receipts. While private remittances generally have been strong over the years, they are vulnerable to social and political crises. Vulnerability also stems from the relatively low and undiversified export base.

49. There are also political risks. Albania's politics has been divisive and confrontational, and is likely to remain so. In this context, uncertainty is created as regards the composition of the government that will be formed after the mid-2005 parliamentary elections.

50. Other multilateral institutions are likely to seek a Fund arrangement to complement their own operations in Albania. The World Bank staff have signaled that a program-based Fund engagement in Albania over the coming period will be an important consideration for the Bank's future intervention under the next four-year Country Assistance Strategy, currently in preparation. The European Commission has recently approved its macroeconomic financial assistance to Albania for 2005, and disbursements (in two tranches in March and September/October) will be subject to a Fund arrangement being in place.

51. To maintain a stable macroeconomic environment and address the shortcomings in the institutional and governance frameworks, the policy agenda will need to comprise:

- An appropriately tight fiscal stance to create adequate room for private credit growth and to safeguard fiscal and external sustainability. Its specific parameters should be set on the basis of a realistic assessment of the prospects for private national saving - in particular, private remittances - and availability of external financing. 
- Increased efforts to (i) enhance tax and customs administration, particularly in the areas of audit and enforcement for both direct and indirect taxes; (ii) integrate social insurance collections with tax administration; and (iii) enlarge the tax base. Priority should be given to strengthening capacities of the directorates of taxation and customs to implement their reform agenda - as such, the FAD TA reports considered the reform program to be comprehensive and generally well designed and noted that the tax rates were comparable to regional levels. Budget revenue projections ought to be based on a realistic assumption of revenue gains from improvements in tax administration.

- Improving expenditure prioritization and management, so as to find additional resources for priority spending and for poverty reduction goals within the constraint of the overall fiscal envelope. In this context, minimizing wage drift in the budgetary sector, following through on reforms of public administration and expenditure management, and improving aid coordination and properly reflecting aid flows in the budget are warranted. Focus should remain on selective wage increases in the public sector for attracting and retaining highly-qualified staff, and across-the-board pay increases should be avoided. Consideration ought to be given to introducing within-title steps in the civil service salary scale and to using the promotion process as the primary means of linking pay to performance.

- Strengthening all aspects of debt management and debt budgeting.

- Continued strengthening of supervisory and prudential oversight of banks to guard against stresses on the banking sector. The forthcoming Financial Sector Assessment Program in early 2005 will help identify specific measures required beyond the current initiatives being undertaken under the World Bank's financial sector adjustment credit project.

- More concerted efforts to establish a business-friendly environment necessary for attracting foreign and domestic investments and boosting potential output and exports. The focus of such efforts needs to become more heavily weighted toward implementation aspects. An independent judiciary as well as more effective prosecuting institutions and enforcement machinery would be key to improving governance and rule of law. The reform agenda should also take care of the main supply-side constraints: reducing administrative barriers to investment, completing privatization in the strategic enterprises, and upgrading and modernizing infrastructure.

- Improving the quality, coverage, and timeliness of economic statistics. The key areas requiring attention include national accounts and real activity indicators, and selected elements of balance of payments statistics - notably, remittances, financial account transactions, and foreign investment. In addition, improvements are needed with regard to the monitoring of foreign assistance and external debt. 
52. Given the extensive structural reform agenda and nature of the tasks, a program supported by the Fund would need to have a medium term dimension. Making a determination of the appropriate type of arrangement is beyond the scope of the EPA review. Since the prospective balance of payments needs appear to be limited, a precautionary arrangement is one possibility. But, this may not provide sufficient incentive for maintaining policy discipline and mustering political support for appropriate policies, and might be deemed not sufficiently commensurate with the magnitude of the required reform efforts. Drawings from the Fund upon meeting program conditionality could serve as an important signal for establishing credibility, domestically and externally, in the authorities' commitment to reforms. These considerations would argue in favor of a Fund arrangement with low access. In earlier Board papers, it was anticipated that Albania would be removed from the PRGF eligibility list after the current arrangement expired (see www.imf.org) or would be covered by PRGF/EFF blends (see www.imf.org), given that Albania's per capita income is nearly twice the IDA eligibility threshold. A final decision in this regard will likely need to be made before the current PRGF arrangement expires in June 2005. The World Bank also will be reviewing Albania's IDA eligibility and creditworthiness to borrow on market terms in the next few months. Irrespective of the type of a possible successor arrangement, it would be important to have incentives in place that foster the institutionalization of the participatory process in public policy making, which is only now beginning to take root, and sustain the focus on poverty reduction efforts.

\section{Effective Bank-Fund collaboration would be essential, since many of the} required reforms are in areas in which the World Bank has taken the lead. Given the heightened role expected of the budget formulation process and expenditure management in meeting the various dimensions of the fiscal objectives of the program, measures in these areas and civil service reform might have to be incorporated into conditionality under a Fund arrangement to a greater extent than in the past. Conditionality also would need to cover the key recommendations of the forthcoming FSAP on financial sector reform. In addition, it would be desirable to include in conditionality aspects of law enforcement that had a bearing on revenue collection and loan recovery by banks, which would test progress in governance as well. Thus, early coordination between the Bank and Fund staff on the pace of reform implementation would be necessary. Conditionality should be pointed and strike at the core of the problem. A challenge for both institutions will be to develop appropriate performance indicators on implementation aspects of reform for specifying structural conditionality and monitoring progress; the Fund should not hesitate to interrupt drawings under an arrangement if overall performance in the structural area turns out to be unsatisfactory.

\section{When would it be appropriate for the Fund to exit from a program-based}

relationship with Albania? For some of the other transition countries in the region with longer-term Fund engagement, the proximity of EU accession is seen as providing an alternative to the discipline that may be associated with Fund support. However, the experience of these countries shows that a Stabilization and Association Agreement with the EU and access to international capital markets do not necessarily guarantee sufficient anchors for policy discipline and institution building. In any event, Albania is a long way 
from joining the EU. Still, despite the already long program engagement, there does not seem any overwhelming reason why the Fund should not continue to have a program-based engagement with Albania for some time to come-assuming that programs are appropriately strong and that the authorities continue to implement them well-until the task of institution and capacity building is sufficiently advanced or until appropriate anchors in support of prudent policies are in place. The appropriate timing of the transition to a surveillance-only relationship could be assessed toward the end of the next Fund arrangement with Albania.

\section{Conclusions}

\section{The EPA team reached a number of conclusions:}

- The Fund's longer-term engagement in Albania occurred within the context of generally successful programs. Implementation of financial policies in line with the Fund's advice was instrumental in establishing and maintaining macroeconomic stability. The Fund also played an important role in providing a blueprint for structural reforms. Judging by the record on meeting conditionality, implementation of structural measures in areas within the mandate of the Fund was uneven, but satisfactory overall.

- Albania's structural reform agenda remains unfinished. In part, this reflects the enormity and complexity of reforms - on account of Albania's extremely poor starting conditions - and administrative capacity constraints. However, divisive politics and weak governance also hindered the pace of reform. The Fund staff took adequately into account political economy factors. Thus, when sufficient ownership of the program agenda was not forthcoming in 1996 and when political uncertainties were mounting in 2001-02, the Fund disengaged from a program mode and delayed the start of the arrangement, respectively. These decisions likely enhanced the Fund's credibility.

- The financial pyramid scheme crisis in early 1997 was a watershed for the country. The crisis revealed the fundamental problems in governance. Following the crisis and with the change in government, reforms became more broad-based and the commitment to them strengthened. In particular, financial sector reforms - neglected in the initial phase of transition - received a boost.

- The programs supported by the Fund showed a consistent trend of over optimism with regard to projections for tax revenues and foreign-financed capital expenditure. The focus on unrealistic tax revenue targets, together with inadequate staffing, likely detracted the attention of officials from pursuit of tax administration reform efforts. Revenue and foreign financing shortfalls triggered expenditure cuts, some of which were in priority areas such as health and education. This experience suggests that expenditure prioritization and 
management as well as donor coordination of aid and technical assistance should have been addressed early on in the reform process.

- Detailed structural conditionality is likely to have played a useful role in coordinating domestic policies. On the whole, the coverage of conditionality was appropriate, and the significant reliance on prior actions strengthened implementation. However, in some areas - especially, privatization - the timetable may have been ambitious and did not take due account of the prevailing difficult market environment.

- Looking forward, the macroeconomic challenges and unfinished reform agenda suggest a continued program-based engagement by the Fund. A new program should contain measures to preserve fiscal and external sustainability while creating room for private sector credit growth. At the same time, sustained commitment to a multi-pronged structural reform agenda is warranted-including strengthening bank supervision, further upgrading tax and customs administration, enhancing public expenditure management, and improving the overall business environment through addressing governance weaknesses and infrastructure needs. Focusing on policy implementation will be vital, and will require effective upstream collaboration with the World Bank to ensure a consensus on the coverage and prioritization of key structural measure 